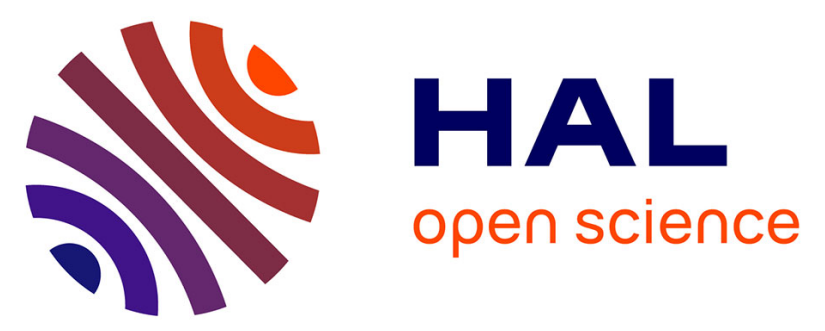

\title{
ABCA7 Downregulation Modifies Cellular Cholesterol Homeostasis and Decreases Amyloid- $\beta$ Peptide Efflux in an in vitro Model of the Blood-Brain Barrier
}

Yordenca Lamartinière, Marie-Christine Boucau, Lucie Dehouck, Markus

Krohn, Jens Pahnke, Pietra Candela, Fabien Gosselet, Laurence Fenart

\section{To cite this version:}

Yordenca Lamartinière, Marie-Christine Boucau, Lucie Dehouck, Markus Krohn, Jens Pahnke, et al.. ABCA7 Downregulation Modifies Cellular Cholesterol Homeostasis and Decreases Amyloid- $\beta$ Peptide Efflux in an in vitro Model of the Blood-Brain Barrier. Journal of Alzheimer's Disease, 2018, 64 (4), pp.1195-1211. 10.3233/JAD-170883 . hal-02506137

\section{HAL Id: hal-02506137 \\ https://hal-univ-artois.archives-ouvertes.fr/hal-02506137}

Submitted on 19 Jul 2021

HAL is a multi-disciplinary open access archive for the deposit and dissemination of scientific research documents, whether they are published or not. The documents may come from teaching and research institutions in France or abroad, or from public or private research centers.
L'archive ouverte pluridisciplinaire HAL, est destinée au dépôt et à la diffusion de documents scientifiques de niveau recherche, publiés ou non, émanant des établissements d'enseignement et de recherche français ou étrangers, des laboratoires publics ou privés. 


\title{
ABCA7 Downregulation Modifies Cellular Cholesterol Homeostasis and Decreases Amyloid- $\beta$ Peptide Efflux in an in vitro Model of the Blood-Brain Barrier
}

\author{
Yordenca Lamartinière ${ }^{\mathrm{a}}$, Marie-Christine Boucau ${ }^{\mathrm{a}}$, Lucie Dehouck ${ }^{\mathrm{a}}$, Markus Krohn ${ }^{\mathrm{b}}$, \\ Jens Pahnke ${ }^{\mathrm{b}, \mathrm{c}, \mathrm{d}}$, Pietra Candela ${ }^{\mathrm{a}}$, Fabien Gosselet ${ }^{\mathrm{a}, 1, *}$ and Laurence Fenart ${ }^{\mathrm{a}, 1}$ \\ ${ }^{a}$ Université d'Artois, EA 2465, Laboratoire de la Barrière Hémato-Encéphalique (LBHE), France \\ ${ }^{\mathrm{b}}$ Department of Neuro-/Pathology, University of Oslo (UiO) \& Oslo University Hospital (OUS), Oslo, Norway \\ ${ }^{\mathrm{c}}$ University of Lübeck (UzL), LIED, Lübeck, Germany \\ ${ }^{\mathrm{d}}$ Leibniz Institute of Plant Biochemistry (IPB), Halle, Germany
}

Accepted 30 May 2018

\begin{abstract}
The role of ABCA7 in brain homeostasis and Alzheimer's disease (AD) is currently under intense scrutiny, since it has been reported that polymorphisms in the $A b c a 7$ gene and a loss of function of the protein are closely linked to excessive accumulation of amyloid peptides and disturbed cholesterol homeostasis. The blood-brain barrier (BBB), which isolates the brain from the blood compartment, is involved in both of these processes. We therefore hypothesized that ABCA7 downregulation might affect cholesterol and amyloid exchanges at the BBB. Using siRNA and primary cultures of mouse endothelial cells purified from brain microvessels and seeded on Transwell ${ }^{\circledR}$ inserts, we investigated the role of ABCA7 in cholesterol and amyloid exchanges across the BBB. Our results showed that a decrease in ABCA7 expression at the BBB provokes in vitro a reduction in ABCA1 expression and a decrease in APOE secretion. In vitro, these decreases reduce cholesterol exchange across the BBB, particularly for high-density lipoproteins and ApoA-I particles. When ABCA7 was absent, we observed a reduction in $\mathrm{A} \beta$ peptide basolateral-to-apical transport in the presence of ApoA-I, with non-significant changes in the expression levels of Rage, $L r p 1, A b c b 1, A b c c 1$, and Abcg2. Our study in murine BBB model highlighted a putative new role for $\mathrm{ABCA} 7$ in $\mathrm{AD}$ via the protein's involvement in cholesterol metabolism and amyloid clearance at the BBB.
\end{abstract}

Keywords: ABCA7, A $\beta$ peptides, Alzheimer's disease, blood-brain barrier, cholesterol metabolism

\section{INTRODUCTION}

In developed countries, Alzheimer's disease (AD) is the most prevalent form of dementia in the

\footnotetext{
${ }^{1}$ Joint last authorship.

*Correspondence to: Fabien Gosselet, Blood-Brain Barrier Laboratory, Université d' Artois, Jean Perrin Faculty, Rue Jean Souvraz, F-62300 Lens, France. Tel.: +33 321791 733; Fax: +33 321 791 736; E-mail: fabien.gosselet@univ-artois.fr.
}

elderly [1]. One of the pathological hallmarks of this neurodegenerative disease is the accumulation of amyloid- $\beta$ peptides $(A \beta)$ in brain parenchyma and cerebral blood vessel walls [2]. It has been clearly demonstrated that the majority of late-onset cases of $\mathrm{AD}$ are associated with several risk factors linked to cholesterol metabolism and transport [3, 4]. For example, the apolipoprotein E $\varepsilon 4(A P O E \varepsilon 4)$ allele is the strongest genetic risk factor for sporadic, 
late-onset $\mathrm{AD}$. The ApoE4 protein is the main cholesterol carrier in brain tissue and is thus involved in regulation of cholesterol metabolism in the brain. The $A P O E \varepsilon 4$ allele is also known to promote $\mathrm{A} \beta$ aggregation [5]. In contrast, the APOE $\varepsilon 2$ allele is associated with protection against AD. Moreover, a highcholesterol diet and thus hypercholesterolemia are associated with $\mathrm{AD}$. In preclinical studies of murine AD models, the hypercholesterolemia induced by a cholesterol-enriched diet was associated with an elevated level of $A \beta$ peptides in the brain [6], whereas $\mathrm{A} \beta$ deposition was lower when mice were treated with cholesterol synthesis inhibitors [7]. Thus, the level of cholesterol in the blood can modify $\mathrm{A} \beta$ peptide levels in the brain $[6,8,9]$. These effects are seen despite the presence of the blood-brain barrier (BBB), which restricts the passage of several molecules (including cholesterol) from the circulation into the brain. The key structural components of the BBB are the brain endothelial cells (BECs), which are sealed together by tight junctions. Therefore, the passage of molecules across the BBB is facilitated by transporters that are expressed at the BECs' luminal and/or abluminal membranes.

These transporters include members of the ATPbinding cassette (ABC) superfamily, which use ATP hydrolysis to transport a wide range of molecules against their concentration gradients and thus participate in the maintenance of the brain's microenvironment [10]. At the $\mathrm{BBB}, \mathrm{ABCA} 1$ contributes to cholesterol efflux $[11,12]$ by transferring lipids to apolipoproteins and initiating high-density lipoprotein (HDL) formation [13]. Other ABC transporters involved in the lipidation/maturation of lipoproteins are also expressed at the BBB $[11,14]$, although their exact roles require further characterization $[15,16]$. Thus, ABC transporters are major players in cholesterol efflux and lipoprotein metabolism [13, 17], and confer the BBB with an important role in the regulation of brain cholesterol levels [18].

Interestingly, genome-wide association studies (GWASs) of AD have never identified singlenucleotide polymorphisms in members of the ABC transporter superfamily as possible genetic factors albeit with the exception of $A B C A 7$, for which loss of function is associated with an increased risk of developing $\mathrm{AD}[19,20]$.

In the periphery, ABCA7 participates in cholesterol efflux to ApoE discs in kidney cells [21], although cholesterol release is not affected in macrophages from $A b c a 7$ knockout (KO) mice [22]. In the brain, $A b c a 7$ is strongly expressed in several different cell types but is particularly present in microglia [23]. It has been demonstrated that $\mathrm{ABCA} 7$ is involved in phagocytosis and in $A \beta$ clearance by microglia [24]. In neurons, ABCA7 deficiency alters the lipid profile and promotes $A \beta$ peptide production through increased BACE 1 expression [25]. Despite the fact that $A B C A 7$ expression has been detected in an in vitro model of the BBB [14], its function at this barrier has not previously been studied.

By using RNA silencing, a mouse-based in vitro model of the BBB [26-28], the objective of the present study was to characterize the effect of ABCA7 deficiency on cholesterol and amyloid exchanges at the BBB.

Our in vitro results show that ABCA7 deficiency induced a decrease in ABCA1 and APOE expression, as well as a decrease in cholesterol efflux towards ApoA-I and HDL particles. When ABCA7 is downregulated, a decrease in $A \beta$ peptide efflux across the BBB is observed in the presence of ApoA-I. Taken as a whole, our results highlight a role for ABCA7 in brain cholesterol metabolism and in $A \beta$ peptide clearance across the BBB. The results may also explain (at least in part) the association between $\mathrm{ABCA} 7$ and $\mathrm{AD}$.

\section{MATERIALS AND METHODS}

\section{Chemicals}

siRNA and 5X siRNA buffer were purchased from Dharmacon (Velizy-Villacoublay, France). Lyophilized siRNA was reconstituted in 1X siRNA buffer at a concentration of $5 \mu \mathrm{M}$. ApoA-I and HDL were purchased from VWR (Fontenay-sous-Bois, France). Transfection reagent Ribocellin, ApoE2 and ApoE4 were purchased from Clinisciences (Nanterre, France). Lyophilized ApoE2 and E4 were reconstituted in sterile water at a concentration of $1 \mathrm{mg} / \mathrm{mL}$. Lucifer yellow (LY), FITC-inulin and bovine serum albumin (BSA) were purchased from Sigma-Aldrich (Lyon, France). $\left[{ }^{3} \mathrm{H}\right]$-cholesterol $(40-60 \mu \mathrm{Ci} / \mathrm{mmol})$ was purchased from Biotrend (Köln, Germany) and $\left[{ }^{14} \mathrm{C}\right]$-sucrose was bought from Perkin Elmer Life and Analytical Sciences (Waltham, MA, USA). Fluorescent $A \beta_{40}$-Cy5 labeled was purchased from Phoenix Pharmaceuticals (Strasbourg, France).

\section{Cell culture reagents}

Most reagents were purchased from SigmaAldrich: HEPES $1 \mathrm{M}$, amino acids 50X, vitamins 
100X, tosyl-lysine-chloromethyl-ketone (TLCK), Hanks balanced saline solution (HBSS) 1X, dextran and basic fibroblast growth factor (bFGF). L-glutamine was obtained from Merck (Fontenaysous-Bois, France). Dulbecco's modified Eagle's medium (DMEM) was purchased from Life Technologies (Illkirch, France). DNase I and collagenase/ dispase were purchased from Roche Diagnostics (Meylan, France). Matrigel was purchased from BD Biosciences (Le Pont de Claix, France) and Transwell ${ }^{\circledR}$ polyester membrane inserts (pore size: $0.4 \mu \mathrm{m}$ for all experiments) were obtained from Corning (Corning, NY, USA). Newborn calf serum (CS) was obtained from Integro B.V. (Zaandam, The Netherlands).

\section{Animal experiments}

In accordance with French legislation, the animal facility at the University of Artois has been approved by the local authorities (reference: B62498-5). In compliance with European Union legislation (Directive 2010/63/EU), all procedures were approved by the local Animal Care and Use Committee (Comité d'Éthique en Expérimentation Animale du Nord-Pas-De-Calais; reference: C2EA 75 ) and the French Ministry of Research (reference: 2015090115412152). For in vitro experiments, 4- to 6-week-old C57BL/6 mice were provided by Janvier Labs (Le Genest-Saint-Isle, France).

\section{Cell culture}

The in vitro $\mathrm{BBB}$ model consisted of a primary monoculture of mouse brain capillary endothelial cells (MBCECs) seeded on filters coated with Matrigel ${ }^{\circledR}$ [26-28]. Briefly, after removing the meninges and the outer vessels, cortices were homogenized in HBSS containing $10 \mathrm{mM}$ HEPES and $0.1 \%$ BSA (WBB buffer) using a Dounce homogenizer. The resulting homogenate was mixed with $30 \%$ dextran (v/v, molecular weight 100,000-200,000) in HBSS and then centrifuged to discard neural cells. The pellet containing the vascular component was resuspended in HBSS and then filtered through a $59 \mu \mathrm{m}$ nylon mesh, in order to retain larger vessels on the mesh surface while capillaries passed through. The resulting capillary-enriched fraction was digested with collagenase/dispase $(2 \mathrm{mg} / \mathrm{mL})$ for $33 \mathrm{~min}$ at $37^{\circ} \mathrm{C}$ in WBB by supplemented with $10 \mu \mathrm{g} / \mathrm{mL}$ DNase and $0.147 \mu \mathrm{g} / \mathrm{mL}$ TLCK. Next, the resulting capillary suspensions were seeded on
Matrige ${ }^{\circledR}$-coated inserts $(51,000$ digested capillaries $/ \mathrm{cm}^{2}$ ) and cultured in DMEM supplemented with $15 \% \mathrm{CS}, 2 \mathrm{mM}$ glutamine, $1 \mathrm{X}$ amino acids, $1 \mathrm{X}$ vitamins, $50 \mu \mathrm{g} / \mathrm{mL}$ gentamycin and $1 \mathrm{ng} / \mathrm{mL}$ bFGF. Remaining cellular debris and red blood cells were removed by washing with medium $24 \mathrm{~h}$ after seeding.

\section{siRNA treatment}

Twenty-four hours after seeding, endothelial cells were transiently transfected with $40 \mathrm{nM}$ mouse $\mathrm{Abca} 7$ siRNA (treated condition, siABCA7 cells) or untargeted siRNA (the control condition) according to the manufacturer's instruction (protocol D-044433-030005, GE Healthcare, Velizy-Villacoublay, France). First, the siRNA was incubated with 1X siRNA buffer and the transfection reagent Ribocellin for $15 \mathrm{~min}$ at room temperature (RT). Next, warmed cell culture medium (with no added antibiotic) was added to the solution. Lastly, cells were incubated with siRNA cell culture medium supplemented with $1 \mathrm{ng} / \mathrm{mL}$ bFGF for $60 \mathrm{~h}$ at $37^{\circ} \mathrm{C}$ in a $5 \% \mathrm{CO}_{2}$ incubator. The medium was refreshed, and experiments were performed $24 \mathrm{~h}$ after.

\section{BBB permeability measurements}

Permeability to LY was used to check the MBCECs' tightness, as previously described [29]. Filter inserts were transferred in a 12-well plate containing warm, HEPES-buffered Ringer's solution (RH buffer, pH 7.4, HEPES $5 \mathrm{mM}$; $\mathrm{NaHCO}_{3} 6 \mathrm{mM}$; $\mathrm{NaCl} 150 \mathrm{mM}$; KCl $5.2 \mathrm{mM} ; \mathrm{CaCl}_{2} 2.2 \mathrm{mM} ; \mathrm{MgCl}_{2}$ $\left.+6 \mathrm{H}_{2} \mathrm{O} 1.2 \mathrm{mM}\right)$, and a solution of $\mathrm{LY}(50 \mu \mathrm{M})$ was added on the luminal side of the filter. Every $20 \mathrm{~min}$ for $1 \mathrm{~h}$, the filter inserts were transferred into another well containing fresh RH. LY fluorescence was measured with a Synergy H1 multiplate reader (Biotek, Winooski, VT, USA). Lastly, the permeability coefficient was calculated as described by Cecchelli et al.

\section{Immunostaining}

MBCECs were rinsed twice with warmed CMFPBS and then fixed for $1 \mathrm{~min}$ in cold methanol/ acetone (v/v). After three washes with CMF-PBS, the filters were cut from the plastic insert and (to avoid nonspecific binding) incubated for $30 \mathrm{~min}$ in CMFPBS with $10 \%$ normal goat serum. The cells were then incubated with the primary antibody (anti-ZO-1; dilution: 1/200; anti-claudin 5 (dilution: 1/100; both 
from Invitrogen, Cergy-Pontoise, France) diluted in CMF-PBS supplemented with 2\% NGS for $1 \mathrm{~h}$. After three washes in CMF-PBS with $2 \%$ NGS, the cells were incubated in the diluted secondary antibody (AlexaFluor 488/568; Invitrogen) for $60 \mathrm{~min}$. Nuclei were stained with Hoechst 33258 reagent. Lastly, after a wash with CMF-PBS with 2\% NGS followed by three washes with CMF-PBS, the cells were mounted using Mowiol reagent containing Dabco (Sigma-Aldrich). A Cool SNAP RS Photometrics camera (Leica Microsystems) was used to acquire the images, which were then processed using Adobe Photoshop software (Adobe Systems, San Jose, CA, USA).

\section{mRNA extraction and reverse}

transcription-quantitative polymerase chain reactions

Twenty-four hours after the end of siRNA treatment and refreshment of the medium, MBCECs were rinsed twice in sterile cold phosphate buffered saline buffer and lysed using RLT lysis buffer (Qiagen, Valencia, CA, USA). Three filters were pooled for each condition. Total RNA was purified using an RNeasy total RNA extraction kit (Qiagen), according to the manufacturer's instructions. Next, each sample's purity and concentration were assessed by measuring absorbance at $260 / 280 \mathrm{~nm}$ using a Take 3 microplate reader (Synergy ${ }^{\mathrm{TM}} \mathrm{H} 1$, Biotek). Reverse transcription was performed with $250 \mathrm{ng}$ of mRNA and iScript ${ }^{\mathrm{TM}}$ Reverse Transcription Supermix (Bio-Rad Laboratories, Marnes-la-Coquette, France), according to the manufacturer's instructions. cDNA from each sample was amplified by realtime PCR using the SsoFast ${ }^{\mathrm{TM}}$ EvaGreen Master Mix kit (Bio-Rad Laboratories) and custom-designed primers. The sequences used for primer design and primer sequences are listed in Table 1 . The amplification consisted of 40 cycles with an annealing temperature of $60^{\circ} \mathrm{C}$, using a CFX96 thermocycler (Bio-Rad Laboratories). The specificity of amplification was assessed by melting curve analysis. mRNA levels were quantified using the comparative CT method and normalized against the reference genes Actb and Hprt.

\section{Protein extraction and immunoblots}

MBCECs were rinsed twice in cold CMF-PBS. The cells were scraped off with UT4 lysis buffer (urea $7 \mathrm{M}$, thiourea $4 \mathrm{M}, 4 \%$ 3-[(3-cholamidopropyl) dimethylammonio]-1-propanesulfonate) supplemented with a protease and phosphatase inhibitor cocktail (Sigma). After a freeze/thaw cycle, the cell lysate was centrifuged to eliminate cellular debris. The protein concentration was evaluated using Bradford's method (Bio-Rad Laboratories) after dilution of the samples. Electrophoresis of $25 \mu \mathrm{g}$ (ABCA1) or $35 \mu \mathrm{g}$ (other proteins) of protein was performed in a $4-15 \%$ SDS-PAGE gel (Bio-Rad), followed by electrotransfer onto nitrocellulose membranes (GE Healthcare). Next, membranes were blocked in Tris-buffered saline with $0.1 \%$ Tween and 5\% skimmed milk for $90 \mathrm{~min}$ at RT. Immunoblotting was performed by incubating membranes with dilutions of the appropriate primary antibody (anti-ABCA7; dilution: 1/1000; Proteintech, Manchester, UK; anti-ABCA1 [11, 12, 30, 31]; dilution: 1/1000; Abcam; anti-ABCG4 [32, 33]; dilution: 1/1000; Alpha Diagnostic International, San Antonio, TX, USA; anti-RAGE [34, 35], dilution: 1/1000, Abcam; anti-ABCB1 (C219) [12, 35], dilution: 1/400, GeneTex, Irvine, CA, USA; anti-ABCG2 (BXP-53) [32], dilution: 1/80, Santa Cruz Biotechnology, Dallas, TX, USA; anti-ABCC1 [36], dilution 1/20, Enzo Life Sciences, Farmingdale, NY, USA; anti-LRP1 [35, 37], dilution 1/200, Santa Cruz Biotechnology and anti- $\beta$-actin, dilution: $1 / 20000$, Sigma) overnight at $4{ }^{\circ} \mathrm{C}$ with slight agitation.

After rinsing, the membranes were incubated with horseradish-peroxidase-conjugated secondary antibodies (Dako and Millipore) for $1 \mathrm{~h}$ at RT. Immunoreactions were developed using an enhanced chemiluminescence kit (GE Healthcare) and revealed on chemiluminescence-sensitive films (GE Healthcare). The bands' relative densities were measured using TotalLab TL 100 1D Gel Analysis software (Nonlinear Dynamics, Newcastle, UK). In these experiments, each deposit represented a pool of at least eight inserts per condition. Each experiment was performed at least four times.

\section{ApoE detection}

After $60 \mathrm{~h}$ of incubation with siRNA, cells were incubated at $37^{\circ} \mathrm{C}$ with serum-free medium. After $24 \mathrm{~h}$, medium was collected and then centrifuged to eliminate cellular debris. Secreted proteins were precipitated with $20 \%$ trichloroacetic acid (Sigma). Cold acetone was added and the solution thus obtained was centrifuged. Protein pellets were washed twice with cold acetone, and the remaining acetone was airdried. Proteins were resuspended in RIPA lysis buffer 
Table 1

DNA primers and accession numbers used for the qPCR experiments

\begin{tabular}{|c|c|c|c|}
\hline mRNA & $\mathrm{F} / \mathrm{R}$ & Sequence & Accession number \\
\hline \multirow[t]{2}{*}{ Abca7 } & $\mathrm{F}$ & $\begin{array}{l}5^{\prime} \text {-TCTGCTGTGGAAAAATTACA-3' } \\
\text { ' }\end{array}$ & NM_013850.1 \\
\hline & $\mathrm{R}$ & 5'-GACAGCCACTAGGATGAAGA-3' & \\
\hline \multirow[t]{2}{*}{ Abcal } & $\mathrm{F}$ & 5'-CAAGCATCTTCAGTTCATCAGC-3' & NM_013454.3 \\
\hline & $\mathrm{R}$ & $5^{\prime}$-GAGTGTAGCAGGGACCACATAA- $3^{\prime}$ & \\
\hline \multirow[t]{2}{*}{ ApoE } & $\mathrm{F}$ & 5'-CTCCCAAGTCACACAAGAACTG-3' & NM_009696.3 \\
\hline & $\mathrm{R}$ & $5^{\prime}$-TCCTCCAGCTCCTTTTTGTAAG- $3^{\prime}$ & \\
\hline \multirow[t]{2}{*}{ Abcg4 } & $\mathrm{F}$ & 5'-CTGAGGACCTTCCGCAAGATGT-3' & NM_138955 \\
\hline & $\mathrm{R}$ & 5'-GCTTCAGGTTGGCAGAGACCAT-3' & \\
\hline \multirow[t]{2}{*}{ Abcg 1} & $\mathrm{~F}$ & $5^{\prime}$-GGGACTCGGTCCTGACACATCT- $3^{\prime}$ & NM_009593 \\
\hline & $\mathrm{R}$ & 5'-AGGACCTTCTTGGCTTCGTTCC-3' & \\
\hline \multirow[t]{2}{*}{ Abcb1 } & $\mathrm{F}$ & 5'-TGAAATGAAGCTGTTGTCTG-3' & NM_011075.2 \\
\hline & $\mathrm{R}$ & 5'-AATAGTGCGGAAGTTTTCAA-3' & \\
\hline \multirow[t]{2}{*}{ Abcg2 } & $\mathrm{F}$ & $5^{\prime}$-GGTGTCTGTAGCAACACTTCTC-3' & NM_011920 \\
\hline & $\mathrm{R}$ & $5^{\prime}$-TAAAGTACTGAAGCCAGGACAG-3' & \\
\hline \multirow[t]{2}{*}{ Lrp1 } & $\mathrm{F}$ & 5'-CTTGATGGCACAGAGAGAGT-3' & NM_008512.2 \\
\hline & $\mathrm{R}$ & 5'-CATCACACCAGTAGAGCTTG-3' & \\
\hline \multirow[t]{2}{*}{ Rage } & $\mathrm{F}$ & $5^{\prime}$-CCCACCTTATTAGGGACACT-3' & NM_001271424.1 \\
\hline & $\mathrm{R}$ & $5^{\prime}$-TCAAGTCCAACTACCGAGTC-3' & \\
\hline \multirow[t]{2}{*}{ Abcc1 } & $\mathrm{F}$ & $5^{\prime}$-CCCTGTGTACTCACACTTCAAT-3' & NM_008576.3 \\
\hline & $\mathrm{R}$ & 5'-CTACTTTCAGGTCACTCTGGTG-3' & \\
\hline \multirow[t]{2}{*}{ Actb } & $\mathrm{F}$ & 5'-TGACGTTGACATCCGTAAAGAC-3' & NM_007393.5 \\
\hline & $\mathrm{R}$ & 5'-GCAGTAATCTCCTTCTGCATCC-3' & \\
\hline \multirow[t]{2}{*}{ Hprt } & $\mathrm{F}$ & 5'-TCTGGCCTGTATCCAACACTTCG-3' & NM_013556.2 \\
\hline & $\mathrm{R}$ & 5'-AAGCAGTACAGCCCCAAAATGG-3' & \\
\hline
\end{tabular}

supplemented with protease/phosphatase inhibitors (Sigma). The protein concentration was evaluated using Bradford's method (Bio-Rad Laboratories). Equal amounts of total secreted proteins $(20 \mu \mathrm{g})$ were loaded onto 4-15\% SDS-PAGE gel (Bio-Rad Laboratories). Immunoblots were performed as described above, using anti-ApoE primary antibodies (dilution: 1/3000, Abcam). Each experiment was performed three times.

\section{Cholesterol efflux studies}

$\left[{ }^{3} \mathrm{H}\right]$-cholesterol $(0.5 \mu \mathrm{Ci} / \mathrm{mL})$ was incubated with serum for $6 \mathrm{~h}$ at $37^{\circ} \mathrm{C}$. Next, $2 \mathrm{mM}$ glutamine, $1 \mathrm{X}$ amino acids, $1 \mathrm{X}$ vitamins and DMEM were added in order to obtain radiolabeled medium. Cells were incubated with this radioactive medium supplemented with siRNA solution and $1 \mathrm{ng} / \mathrm{mL}$ bFGF for $60 \mathrm{~h}$. After two washes with DMEM/0.05\% BSA, cells were then incubated for $24 \mathrm{~h}$ at $37^{\circ} \mathrm{C}$ with DMEM $/ 0.05 \%$ BSA/bFGF. After this equilibration step, cells were rinsed twice, and cholesterol efflux was assessed for $7 \mathrm{~h}$ in the presence or absence of acceptors $(20 \mu \mathrm{g} / \mathrm{mL}$ HDL, $35 \mu \mathrm{g} / \mathrm{mL}$ ApoA-I, ApoE2 and ApoE4). At the end of efflux experiments, media were collected and centrifuged (4 min, $4000 \mathrm{rpm}, 4^{\circ} \mathrm{C}$ ) in order to remove cellular debris. Lastly, after three washes with cold PBS, cells were lysed with PBS/1\% Triton X-100. Radioactivity in the cell lysates and media was measured in a liquid scintillation counter (Tri-Carb 2100TR). The percentage of cellular cholesterol efflux was calculated from the disintegrations per minute (DPM) using the following equations:

$$
\begin{aligned}
& \text { percentage of luminal efflux } \\
& \quad=\left(\mathrm{DPM}_{\text {luminal }}\right) \times 100 /\left(\mathrm{DPM}_{\text {luminal }}\right. \\
& \left.\quad+\mathrm{DPM}_{\text {abluminal }}+\mathrm{DPM}_{\text {cell lysate }}\right) \\
& \text { percentage of abluminal efflux } \\
& \quad=\left(\mathrm{DPM}_{\text {abluminal }}\right) \times 100 /\left(\mathrm{DPM}_{\text {luminal }}\right. \\
& \left.\quad+\mathrm{DPM}_{\text {abluminal }}+\mathrm{DPM}_{\text {cell lysate }}\right) \\
& \text { percentage of total efflux } \\
& \quad=\left(\mathrm{DPM}_{\text {luminal }}+\mathrm{DPM}\right. \\
& \quad \times 100 /\left(\mathrm{DPM}_{\text {luminal }}+\mathrm{DPM}_{\text {abluminal }}\right) \\
& \left.\quad+\mathrm{DPM}_{\text {cell lysate }}\right)
\end{aligned}
$$

Each assay was performed using three filters, and each experiment was run at least three times.

\section{Quantification of cell cholesterol}

After $60 \mathrm{~h}$ of incubation with siRNA, cells were incubated for $24 \mathrm{~h}$ at $37^{\circ} \mathrm{C}$ with serum-free cell culture medium. After this equilibration step, cells were rinsed with cold RH buffer and then lysed with $1 \mathrm{~N}$ $\mathrm{NaOH}$. One aliquot of the cell lysate (from a single 
insert) was used for the protein concentration assay using Bradford's method (Bio-Rad), and another was homogenized in chloroform/isopropanol/NP-40 (7:11:0.1) for $5 \mathrm{~min}$ with vigorous agitation, in order to extract lipids. After $15 \mathrm{~min}$ of centrifugation at $14000 \mathrm{rpm}$ and $4^{\circ} \mathrm{C}$, the organic phase was collected and then air-dried at $50^{\circ} \mathrm{C}$ for $2 \mathrm{~h}$. The dried lipids were dissolved in the Cholesterol Reaction Buffer provided with a Cholesterol/Cholesteryl Ester Quantitation Kit (Calbiochem) by vortexing vigorously for $5 \mathrm{~min}$. The reaction mixture was prepared according to the manufacturer instructions. Equal volumes of sample and reaction mixture were placed in a 96-well plate and incubated at $37^{\circ} \mathrm{C}$ for $1 \mathrm{~h}$. Next, fluorescence was measured with a Synergy H1 multiplate reader (Biotek) at an excitation wavelength of $535 \mathrm{~nm}$ and an emission wavelength of $587 \mathrm{~nm}$. The amount of cholesterol in each sample was determined with reference to a standard curve and then adjusted as a function of the protein level in each sample. We used three filters for each assay, and each experiment was run three times.

\section{Amyloid- $\beta$ peptide $(A \beta)$ transport studies}

Twenty-four hours after medium refreshment (i.e. following the end of siRNA treatment), MBCECs were rinsed with prewarmed RH buffer. Next, for apical-to-basolateral transport studies, filter inserts were transferred into 12-well plates containing $1.5 \mathrm{~mL}$ of $\mathrm{RH} / \mathrm{BSA} 0.1 \%$ per well. A solution of RH/BSA $0.1 \%$ supplemented with Cy5-A $\beta_{40}$ (10 $\mathrm{nM}),\left[{ }^{14} \mathrm{C}\right]$-sucrose (Perkin Elmer Life and Analytical Sciences, Waltham, MA, USA), FITC-inulin and (or not) ApoA-I ( $200 \mathrm{nM}$ ) was then added (or not) to the apical (luminal) compartment. For basolateral-toapical transport studies, filter inserts were transferred into 12-well plates containing $1.5 \mathrm{~mL}$ of $\mathrm{Cy} 5-\mathrm{A} \beta_{40}$ FITC-inulin in RH/BSA $0.1 \%$, and a solution of $\left[{ }^{14} \mathrm{C}\right]$-sucrose supplemented (or not) with ApoA-I $(200 \mathrm{nM})$ was added in the luminal compartment.

Cells were incubated at $37^{\circ} \mathrm{C}$ with slight agitation. Transport was measured after $3 \mathrm{~h}$. BBB permeability and non-receptor-mediated transport were respectively evaluated by measuring $\left[{ }^{14} \mathrm{C}\right]$-sucrose permeability and FITC-inulin transport. Radioactivity was measured using a liquid scintillation counter, whereas fluorescence was measured using a Synergy H1 spectrophotometer (Biotek). The percentage passage was calculated in the presence and absence of cells, in order to determine the influence of the filter and the coating on transport. The results for inulin were used to normalize the $A \beta$ results, as previously described [31]. The mass balance was also calculated, and the value had to be between $90 \%$ and $110 \%$. Each assay was performed using three filters, and each experiment was run at least three times.

\section{Statistical analysis}

Results were expressed as the mean \pm SEM and analyzed using a Student's T-test or a one-way analysis of variance. All statistical analyses were performed using Prism Software (GraphPad Software Inc., San Diego, CA, USA).

\section{RESULTS}

\section{Abca7 knock-down does not affect the BBB's integrity in vitro}

First, we used an RNA silencing technique to downregulate $A b c a 7$ expression in our murine $\mathrm{BBB}$ model previously described [26-28]. In vitro, Abca7 knock-down resulted in a $58.7 \pm 4.7 \%$ reduction in mRNA expression and a $40 \pm 18 \%$ reduction in protein expression, relative to the control condition (Fig. 1A-C).

We then evaluated the impact of Abca7 downregulation on the BBB's integrity. As shown in Fig. 2A, the MBCECs' paracellular permeability to LY was similar in the siABCA7 and untargeted siRNA conditions $\left(0.41 \pm 0.08 \times 10^{-3} \mathrm{~cm} \cdot \mathrm{min}^{-1}\right.$ and $0.40 \pm 0.07 \times 10^{-3} \mathrm{~cm} \cdot \mathrm{min}^{-1}$, respectively). The value in non-treated cells was $0.34 \pm 0.07 \times 10^{-3} \mathrm{~cm}$. $\min ^{-1}$. Immunofluorescent labeling of the tight junction proteins claudin-5 and ZO-1 showed strong, intact signals at the cell periphery (Fig. 2B) - suggesting that siRNA treatments did not affect the MBCECs' integrity.

\section{Downregulation of Abca7 decreases expression of the transporters involved in cholesterol metabolism and lipid exchanges at the $B B B$}

We then decided to investigate the expression of transporters and acceptors involved in cholesterol metabolism and lipid exchange at the BBB in siRNA-treated cells. In Abca7-depleted cells, mRNA expression levels of Abcal, Abcg4, and $A p o E$ were low (by $53 \pm 5 \%, 34 \pm 4 \%$, and $51 \pm 4 \%$, respectively), whereas $A b c g l$ expression was not significantly different (Fig. 3A). The ABCA1 protein expression levels correlated with the mRNA 


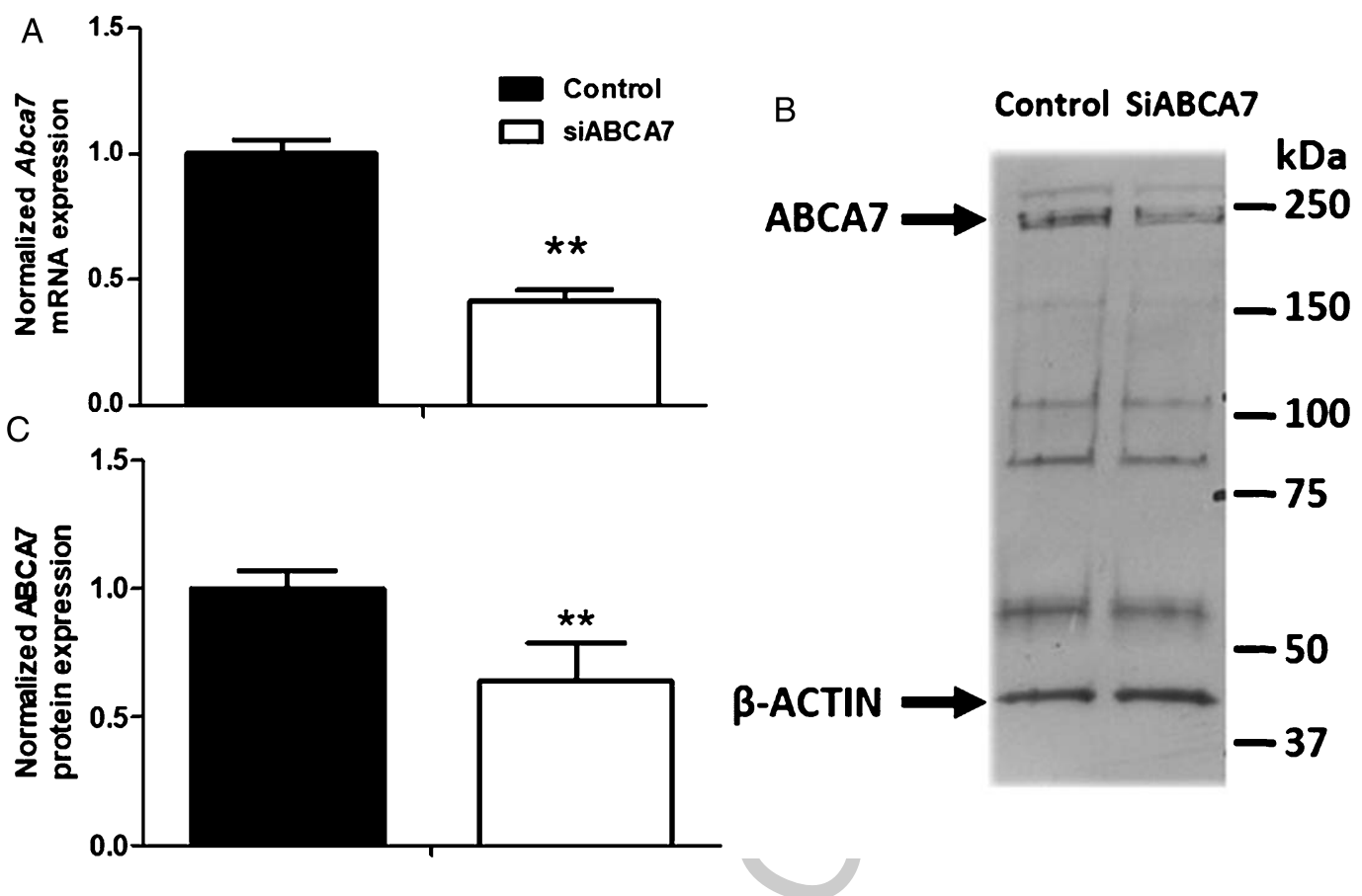

Fig. 1. Effect of siRNA treatment on ABCA7 mRNA and protein expression. A) Transcriptional expression of $A b c a 7$ was assessed in MBCECs using the primers listed in Table 1. Each bar represents the level of mRNA expression normalized against the housekeeping genes Actb and Hprt, relative to the control condition (untargeted siRNA). Data are quoted as the mean \pm SEM of three experiments pooled from three filters. Statistical analysis: $t$-test, ${ }^{* *} p<0.01$. B) Protein levels were assessed by immunoblotting. ABCA7 detection gives unspecific bands as previously reported in mouse brain total extracts [24]. C) Quantification of ABCA7 expression. $\beta$-Actin was used as a loading control. Data are quoted as the mean \pm SEM of at least six experiments pooled from eleven filters. Statistical analysis: $t$-test, ${ }^{* *} p<0.01$.

expression levels (Fig. 3B). Indeed, a statistically significant $38 \pm 13 \%$ relative reduction in the ABCA1 protein level was observed. The ABCG4 protein level was not significantly different (Fig. 3C). Furthermore, the total secreted ApoE fraction was $45 \pm 27 \%$ lower but did not reach statistical significance (Fig. 3D). However, we observed that ApoE secretion was significantly lower in the abluminal media (by $63 \pm 17 \%$ ) but not in the luminal compartment $(18 \pm 44 \%)$.

Thus, ABCA7 deficiency is associated with abnormally low expression of key players in HDL genesis. We therefore next assessed the ability of MBCECs to transfer cholesterol to apolipoproteins and lipoproteins.

\section{Abca7 knock-down is associated with lower cholesterol release from the MBCEC membrane and greater cholesterol accumulation}

The literature data indicate that human, porcine and bovine BBB cells release membrane cholesterol to ApoA-I, ApoE2, ApoE4, and HDL [12, 31, 38].
We therefore investigated the MBCECs' ability to efflux membrane cholesterol in basal conditions in the presence or absence of lipid acceptors. As shown in Fig. 4A, the presence of HDL, ApoE2, and ApoE4 was associated with significantly greater cholesterol release $(6.8 \%, 6.3 \%$ and $7.9 \%$ respectively; i.e., up to 8 -fold greater than the control value $(0.8 \%)$ in the abluminal (brain side) compartment). The same trend was observed for cholesterol efflux to the luminal (blood side) compartment (Fig. 4B), which was promoted in the presence of each of the three lipid acceptors $(11.8 \%, 14.6 \%$, and $15.8 \%$ for HDL, ApoE2, and ApoE4, respectively, compared with the control value of $3.4 \%$ ).

As a consequence, total cholesterol efflux was promoted in the presence of HDL, ApoE2, and ApoE4 (Fig. 4C). No significant differences between the three cholesterol acceptors were observed.

To investigate the impact of $A b c a 7$ downregulation on cholesterol efflux, we then investigated cholesterol release in siABCA7-treated cells. As shown in Fig. 5A and B, we observed significantly lower total cholesterol efflux in the presence of ApoA-I and HDL 

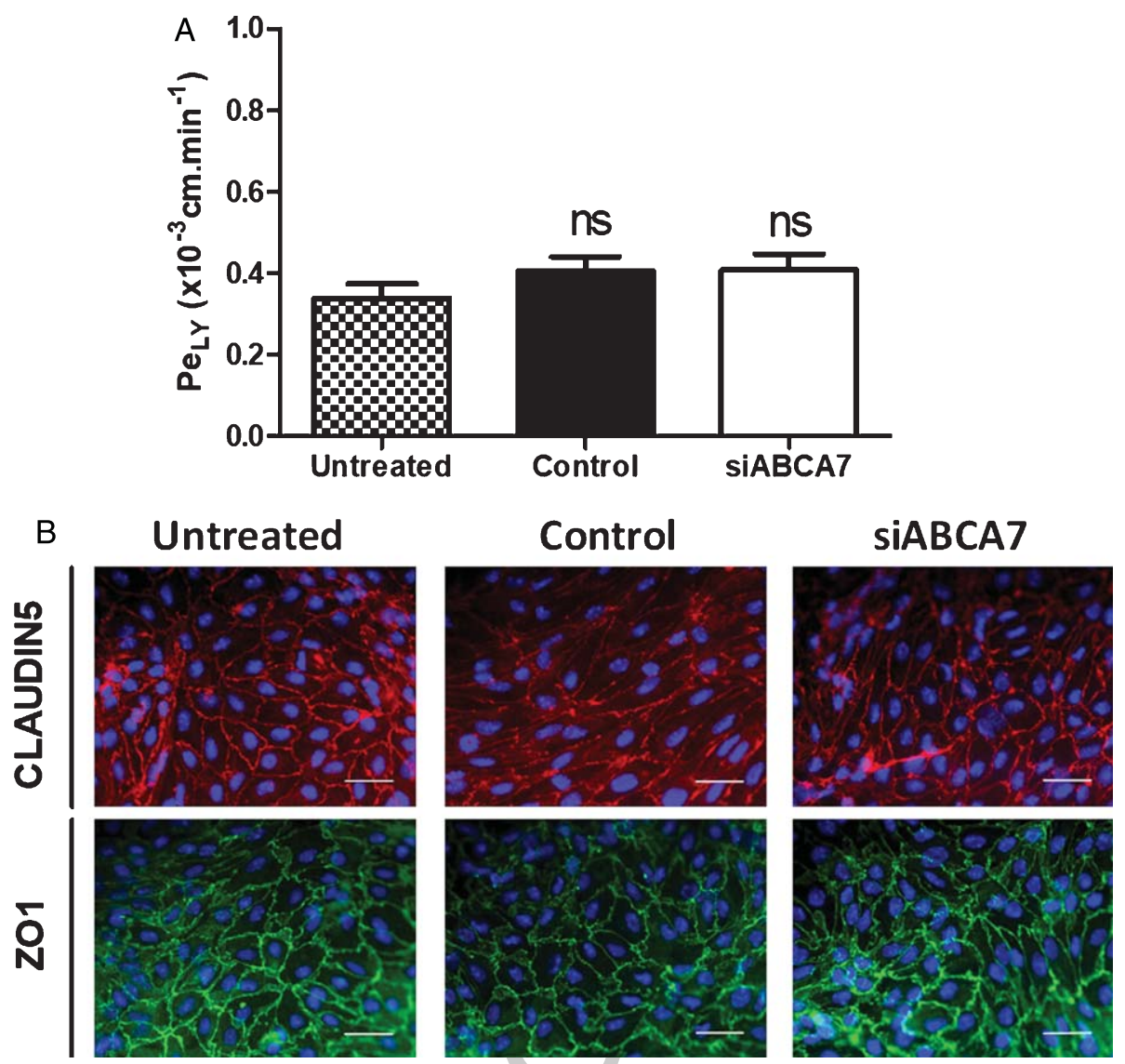

Fig. 2. Effect of siRNA treatment on permeability and tight junction integrity in a monolayer of MBCECs. Endothelial cells were incubated with medium alone (Untreated), untargeted siRNA (Control) or siRNA targeting Abca7 mRNA (siABCA7) for 60 h. Twenty-four hours after the medium had been refreshed, permeability to the paracellular marker LY was evaluated (A). The bars represent the mean \pm SEM of five experiments, each performed with three filters per condition. Statistical analysis was performed using a one-way ANOVA followed by Dunnett's correction for multiple comparisons. ns: non-significant. B) Tight junction integrity was also assessed by immunostaining of claudin 5 (red) and ZO-1 (green). Nuclei were stained with Hoechst 33258 reagent (in blue). Scale bar: $25 \mu \mathrm{m}$.

(32\% and 20\%, respectively, relative to the control). Cholesterol release to the luminal side was lower in the presence of ApoA-I, whereas cholesterol release to both sides was lower in the presence of HDL. These results are in line with those obtained in mouse macrophages in which Abcal and Abca7 have been deleted [39].

In the presence of ApoE4 and ApoE2, total cholesterol release did not significantly differ when comparing siABCA7 cells and the control (Fig. 5C and $\mathrm{D}$, respectively). However, when considering only the abluminal side, ApoE4-mediated cholesterol efflux was reduced by $16 \pm 2 \%$ in siABCA7 relative to the control, whereas ApoE2-mediated cholesterol release was similar in both conditions. Hence, Abca7 knock-down is associated with a relative decrease in cellular cholesterol efflux; this suggests that lipids accumulate in siABCA7 cells, relative to controls.
We thus evaluated the level of cholesterol accumulation in cells. As expected, we found that ABCA7 knock-down promoted a $26 \pm 9 \%$ increase in cholesterol levels in MBCECs, relative to the control condition (Fig. 5E).

\section{ABCA7 knock-down decreases basolateral-to-apical transport of A $\beta$ peptide mediated by ApoA-I}

Given that $A b c a 7^{-1}$ mice show elevated levels of amyloid deposition in the brain [24, 40, 41], we hypothesized that Abca7 downregulation in MBCECs might impact amyloid transport across the BBB. Therefore, apical-to-basolateral and basolateral-to-apical transport assays of $\mathrm{A} \beta$ peptides were performed in our in vitro BBB models, as previously described $[12,31]$. 


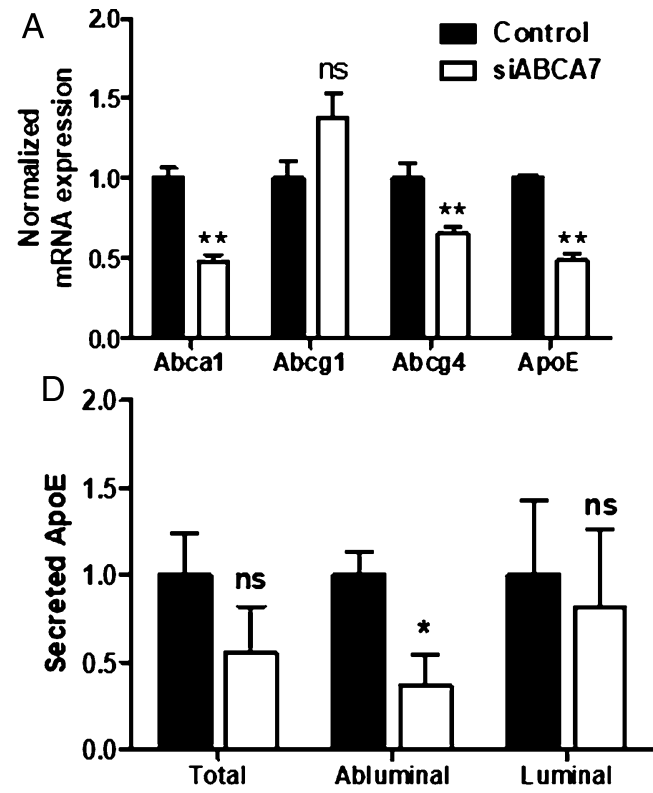

B

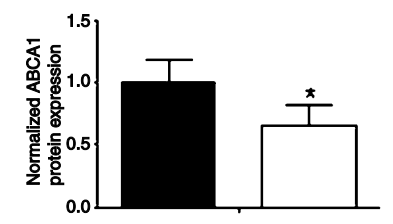

Control SiABCA7

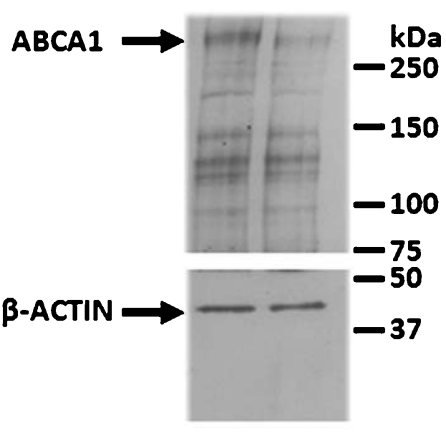

C

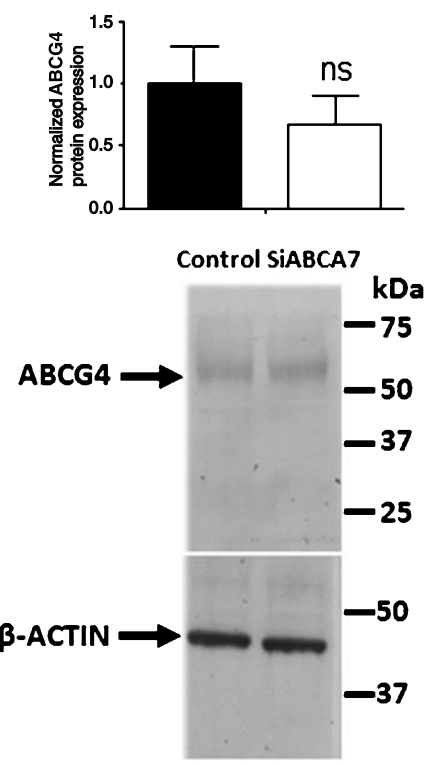

Fig. 3. Effect of Abca7 silencing on the expression of transporters involved in cholesterol release at the BBB. A) For transcriptional expression, each bar represents the level of mRNA expression normalized against the housekeeping genes Actb and Hprt, relative to the control condition. Primers are listed in Table 1. Data are quoted as the mean \pm SEM of three experiments pooled from three filters. Protein levels of ABCA1 (B) and ABCG4 (C) were also evaluated. Actb was used as a loading control. Data are quoted as the mean $\pm \mathrm{SEM}$ of at least four independent experiments pooled from eight filters. Secreted APOE protein was measured in media recovered from luminal and abluminal compartments (D). Data are quoted as the mean \pm SEM of three independent experiments pooled from nine filters. From A to D, statistical analysis: $t$-test, ${ }^{*} p<0.05,{ }^{* *} p<0.01,{ }^{* * *} p<0.001$, ns, non-significant.

As shown in Fig. 6A, ABCA7 downregulation did not directly impact the influx (upper graph) or the efflux of $A \beta_{1-40}$ peptides (lower graph).

We previously reported that the presence of ApoA$I$ in the luminal compartment promotes $A \beta$ peptide efflux [42] and had observed in the present study that luminal ApoA-I lipidation is lower when ABCA7 is downregulated (Fig. 5A). Therefore, we next investigated $\mathrm{A} \beta$ peptide transport in siABCA7 cells in the presence of ApoA-I in the luminal compartment. When ApoA-I was present, we observed a slight but statistically significant relative decrease in basolateral-to-apical transport of A $\beta$ (Fig. 6B, lower graph; $86.5 \pm 3.4 \%$ compared with the control condition in the absence of ApoA-I). No significant differences in apical-to-basolateral transport were observed (Fig. 6B, upper graph).

To obtain additional data on the effect of $A b c a 7$ depletion on the expression of receptors and transporters found to be involved in $A \beta$ clearance by us and others [12, 31, 37, 43-46], we used qRT-PCR and immunoblot assays to measure the mRNA and protein expression of Abcb1,Abcc1, Abcg2, Lrpl, and Rage. Downregulation of $A b c a 7$ was not associated with a difference in expression for any of these genes and proteins (Fig. 7). Despite our efforts, LRP1 and $\mathrm{ABCC} 1$ proteins were not detected, probably because they are expressed at very low level at the endothelial cells of the BBB as previously demonstrated [37, 47, 48].

Taken as a whole, these results suggest that ABCA7 downregulation could alter BBB cholesterol metabolism that in turn could affect amyloid clearance across this barrier.

\section{DISCUSSION}

We and others have demonstrated that the ABCB1 (also known as P-gp), ABCG2 (BCRP) and ABCC1 (MRP1) proteins expressed by endothelial cells of the $\mathrm{BBB}$ can restrict $\mathrm{A} \beta$ entry into the brain and can also mediate $A \beta$ efflux into the blood stream $[34,49,50]$. ABCA1, ABCG1, and ABCG4 are more involved in cholesterol release from cellular membrane, and control cholesterol homeostasis in the brain and lipid exchanges across the BBB. These observations suggested that the modulation of $\mathrm{ABC}$ transporter expression might restore cholesterol metabolism and 

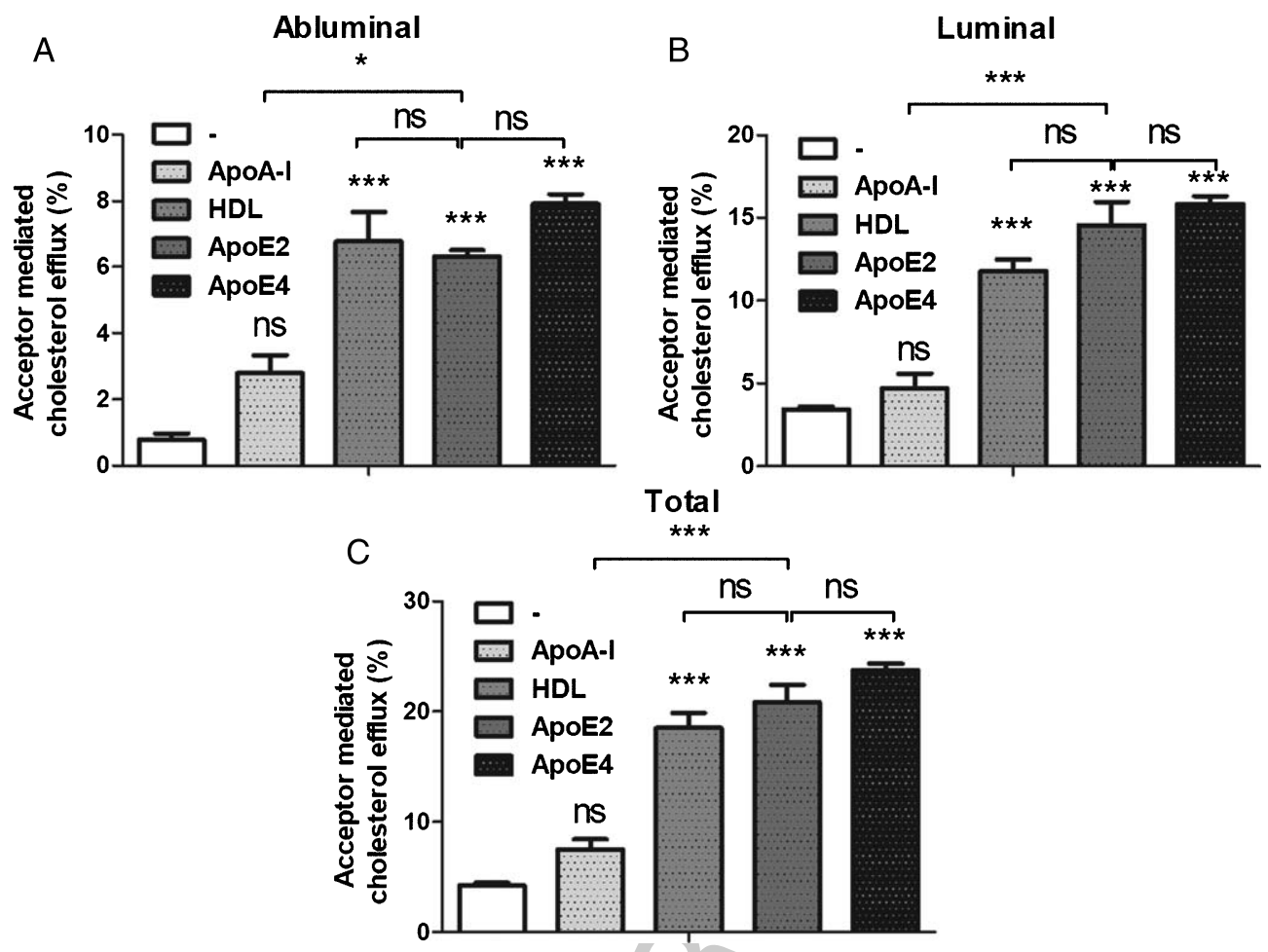

Fig. 4. Basal cholesterol efflux from MBCECs. Cholesterol efflux was assessed for $7 \mathrm{~h}$ in the absence of cholesterol acceptor (DMEM/BSA $0.05 \%$, the control condition) or in the presence of the acceptor ApoA-I $(35 \mu \mathrm{g} / \mathrm{mL})$, HDL $(20 \mu \mathrm{g} / \mathrm{mL})$, ApoE2 (35 $\mu \mathrm{g} / \mathrm{mL})$ or ApoE4 $(35 \mu \mathrm{g} / \mathrm{mL}$ ) in the abluminal (A) and luminal (B) compartments. By summing the levels of cholesterol efflux in the two compartments, we obtained the total cholesterol efflux (C). Data are quoted as the mean \pm SEM of 3 independent experiments representing 7 inserts. Statistical analysis: a one-way ANOVA followed by Bonferroni's correction for multiple comparison, ${ }^{*} p<0.05,{ }^{* *} p<0.01,{ }^{* * *} p<0.001$.

decrease amyloid deposition in AD patients. Promising results were obtained in $\mathrm{AD}$ transgenic mice in which the elevation of $\mathrm{ABCB} 1$ expression (by administering pregnenolone-16 $\alpha$-carbonitrile [51] or caffeine [52]) promoted $\mathrm{A} \beta$ efflux across the BBB. Regarding cholesterol homeostasis, elevated ABCA1 expression in the $\mathrm{AD}$ mouse was associated with less amyloid deposition and less aberrant behavior [53-55]. Furthermore, we recently demonstrated that oxysterols (natural agonists of liver $\mathrm{X}$ receptors) were able to enhance both $\mathrm{ABCA} 1$ and $\mathrm{ABCB} 1$ expression-thus promoting cholesterol exchange and restricting $A \beta$ influx across the $\mathrm{BBB}[31,56]$. Despite these interesting and promising results, however, little is known about the processes that lead to amyloid deposition and cholesterol imbalance in the central nervous system (CNS) of patients with $\mathrm{AD}$. Interestingly, the only $\mathrm{ABC}$ transporter found to be involved in AD in GWASs is $A B C A 7$; very few studies had focused on this protein until the publication of the GWAS results in 2011 [19]. More recent studies have tried to elucidate ABCA7's role in the brain in health and during AD. For example, it was shown that ABCA7 does not have a significant role in the regulation of cell proliferation or neurogenesis in the adult mouse [57], and that the polymorphism identified in $\mathrm{AD}$ patients leads to a loss of function of ABCA7 [20]. Although Abca7 $7^{-1}$ mice exhibit normal sensory abilities, neurological reflexes, and motor functions [58], it is now clear that $A b c a 7^{/-}$ in $\mathrm{AD}$ transgenic mice promotes amyloid deposition. However, some researchers have explained this accumulation by the overproduction of $\mathrm{A} \beta$ peptides [21, $25,40]$ whereas others have suggested that a decrease in microglial phagocytosis was involved [24, 41]. Despite the fact that $A b c a 7$ is known to be expressed at the BBB [14], the effect of a decrease in Abca7 expression on amyloid and cholesterol exchanges across the BBB had not previously been investigated.

Here, we used RNA silencing to decrease Abca7 expression in an in vitro BBB model composed of primary MBCECs [26-28]. We did not observe any change in BBB integrity when Abca7 mRNA and protein expression were downregulated. Given that 

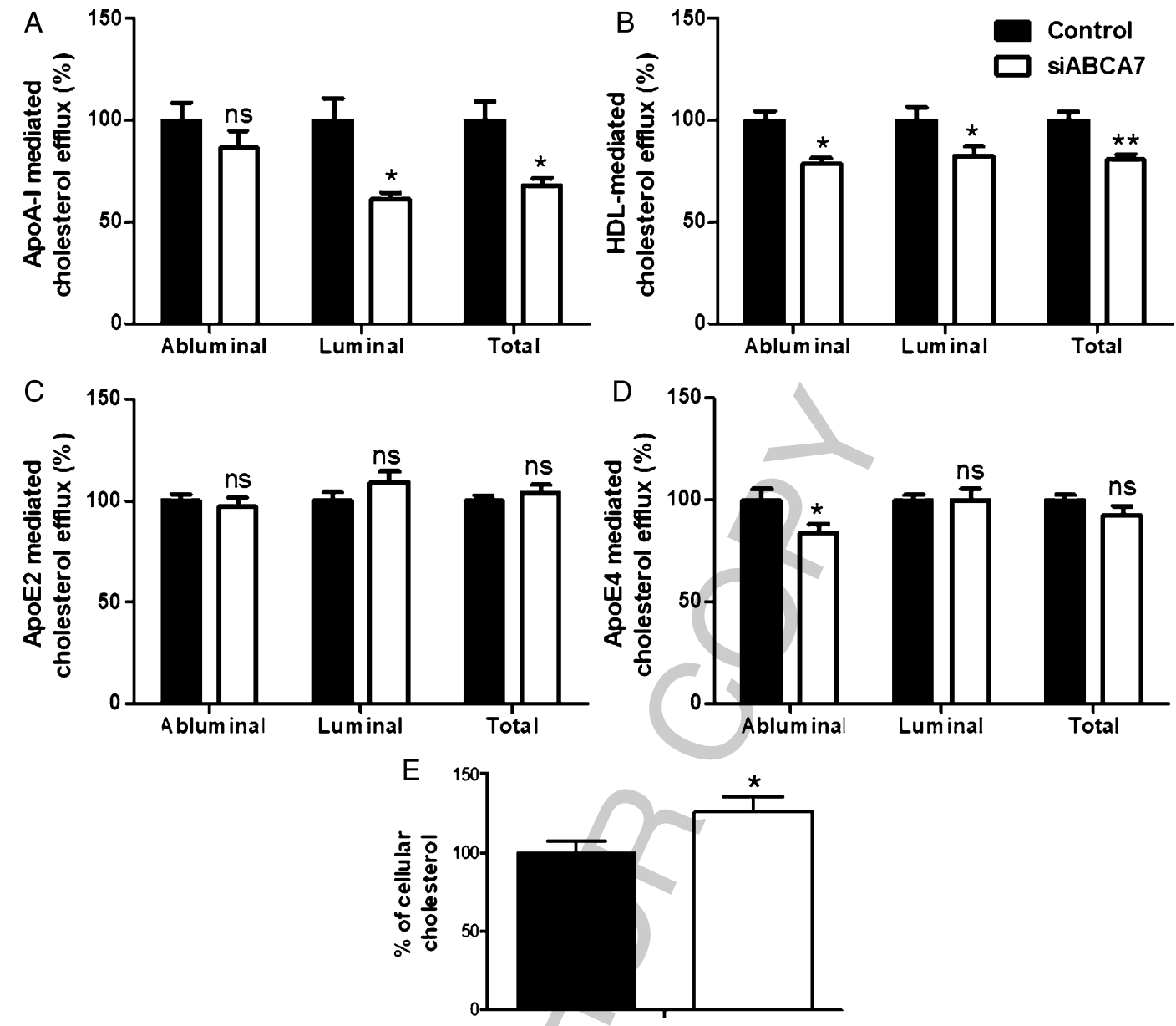

Fig. 5. Effect of $A b c a 7$ knock-down on cholesterol release from MBCECs. As described above, cholesterol efflux was assessed for $7 \mathrm{~h}$ in the presence of various acceptors [ApoA-I (A), HDL (B), ApoE2 (C) and ApoE4 (D)] in control and SiABCA7 cells. Acceptors were added to the luminal and abluminal compartments. Data are quoted as the mean \pm SEM for at least 7 filters from 2 independent experiments. E) Effect of Abca7 knock-down on the cellular cholesterol level. Cholesterol content was assessed in MBCECs after siRNA treatment. Data are quoted as the mean \pm SEM cellular cholesterol level from 9 filters per condition ( 3 independent experiments). Statistical analysis: $t$-test, ${ }^{*} p<0.05,{ }^{* *} p<0.01,{ }^{* * *} p<0.001, \mathrm{~ns}$, non-significant.

ABCA1 and ABCA7 display around 54\% amino acid homology [42] and that ABCA7 generates HDL [21, $59,60]$, we hypothesized that cholesterol exchange across the BBB could be impacted by Abca7 downregulation. Indeed, we observed a relative decrease in cholesterol release (and particularly for HDL and ApoA-I) in this context. However, we cannot be absolutely sure that this relative decrease in cholesterol efflux is directly linked to ABCA7 downregulation because 1) ABCA1 mRNA and protein levels are also lower and 2) we previously demonstrated that ABCA1 is involved in cholesterol efflux to HDL and ApoA-I in human and bovine BBB models [12, $31,56]$. We found no change in the expression of ABCG1, which has been recently identified as a key player in cholesterol metabolism at the BBB
[38]. Abcg4 expression was significantly reduced in vitro when $A b c a 7$ is deleted but protein level was not affected. ABCG4 is exclusively expressed in the CNS and generates (along with ABCA1 and ABCG1) cholesterol rich-HDL [61]. However, this transporter is also involved (along with ABCG1) in the regulation of the intracellular pool of cholesterol in astrocytes and neurons [62]. Therefore, the downregulation of ABCA1 observed in the present study might also explain the decrease in cholesterol release to ApoA-I and HDL and thus the intracellular accumulation of cholesterol.

Interestingly, we also observed lower $A P O E$ expression and lower APOE secretion into the abluminal compartment (mimicking the CNS) of our BBB model. In the CNS, ApoE is required for lipoprotein 
A

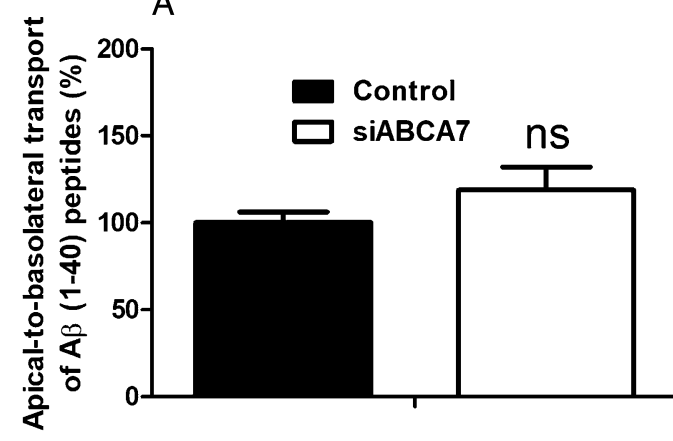

눙
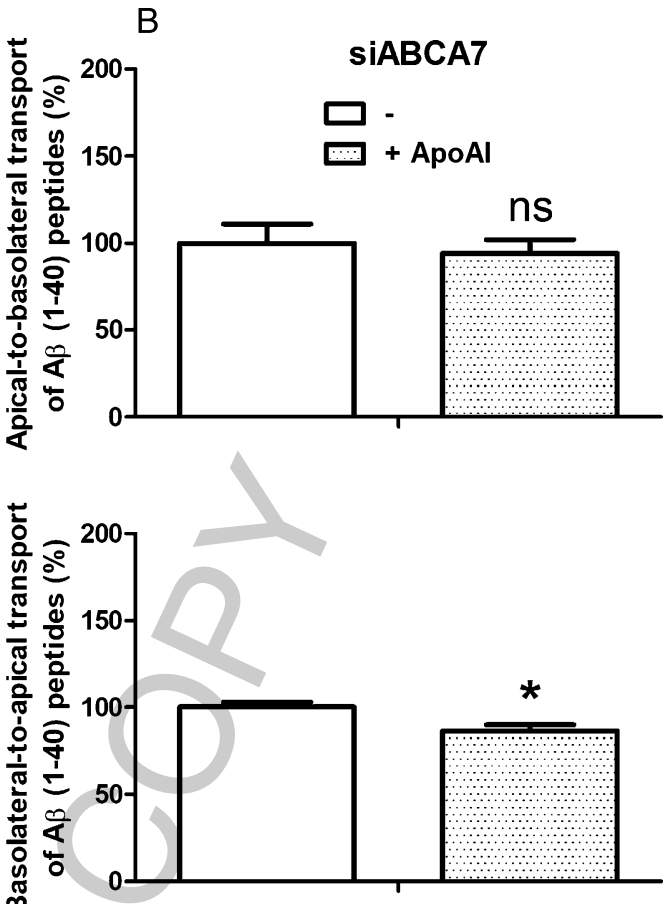

Fig. 6. Effect of $A b c a 7$ knock-down and ApoA-I on A $\beta$ peptide transport across the MBCEC monolayer. A) A $\beta$ peptide transport was assessed for $3 \mathrm{~h}$ in MBCECs treated with untargeted siRNA (Control) or siABCA7. B) The impact of Abca7 downregulation was then investigated in the presence or absence of ApoA-I (200 nM, in the luminal compartment). Inulin was used as a marker of non-specific vesicular transport. Inulin passage was assessed in parallel, and the data were used to normalize the A $\beta$ results. In addition to inulin, paracellular integrity was assessed using radiolabeled sucrose (data not shown) for each experiment. Data are quoted as the mean \pm SEM at least seven filters per condition ( 2 independent experiments). Statistical analysis: $t$-test, ${ }^{*} p<0.05$, ns, non-significant.

uptake into neurons via the LDL family of receptors [63]. ApoE polymorphisms constitute the most common genetic factor involved in $\mathrm{AD}$ [64], and APOE mediates $A \beta$ peptide elimination across the BBB. Downregulation of APOE secretion might lead to a reduction in $\mathrm{A} \beta$ transport across the $\mathrm{BBB}$ and therefore to greater accumulation of these peptides in the brain [64]. Noteworthy, ABCA1 deletion in AD mouse models is also associated with significant reductions in apoE level [65-67].

Our study is not the only one to investigate links between APOE, ABCA1, and ABCA7 regulations. Indeed, in $A b c a 7^{-/}$mice, Kim et al. reported that ApoE levels were not affected when compared with wild-type mice [22]. ABCA1 expression was not modulated in brain. However, in vitro, an upregulation of ABCA7 has been reported in Abcal-deficient mouse fibroblasts [68] whereas Abca7-deficiency in mouse macrophages increases ABCA1 expression [39]. Therefore, all these data suggest that links exist between ABCA7, ABCA1, and APOE but the molecular processes remain largely unknown; they might involve sterol regulatory element binding proteins or liver $\mathrm{X}$ receptors, which are key molecules regulating cholesterol and lipid metabolism [69, 70].

Taken as a whole, these data indicate that by decreasing APOE secretion and ABCA1 expression at the $\mathrm{BBB}, \mathrm{ABCA} 7$ loss of function can significantly alter cholesterol exchange across the BBB and thus promote $\mathrm{AD}$. This is consistent with a previous study reporting the contribution of $\mathrm{ABCA} 7$ in the cerebral lipid metabolism [25].

In addition to lipid metabolism, we also investigated the role of ABCA7 in amyloid transport across the BBB. When ABCA7 was downregulated, we did not observe any difference in amyloid exchange through the BBB in the absence of ApoA-I. However, as discussed above, we found that ABCA7 depletion was associated with a reduction in cholesterol release to ApoA-I; the latter is known to promote $\mathrm{A} \beta$ efflux across MBCECs [71]. Indeed, after adding ApoA-I to the luminal compartment of our experimental set-up, we observed a reduction in the basolateral-to-apical transport of $A \beta$ peptide. Given that the expression of receptors and transporters known to mediate $A \beta$ exchanges across the BBB did not change when 

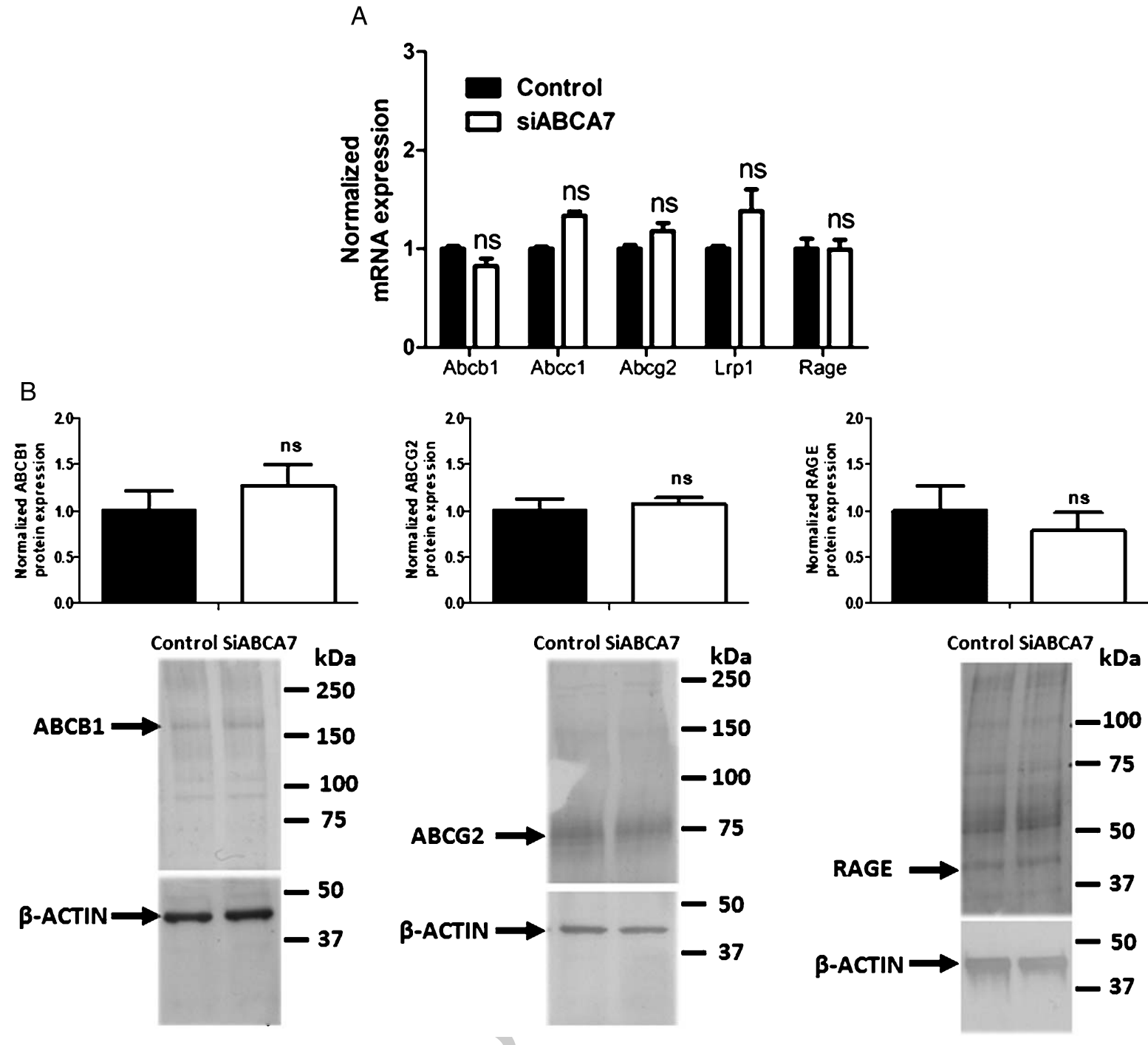

Fig. 7. Effect of $A b c a 7$ silencing on the expression of receptors and transporters involved in A $\beta$ peptide transport at the BBB. A) mRNA levels of key players of amyloid transport were measured by qRT-PCR. Each bar represents the level of mRNA expression normalized against the housekeeping genes Actb and Hprt, relative to the control condition. The primers used are listed in Table 1. Data are quoted as the mean \pm SEM of three independent experiments pooled from three filters. Statistical analysis: $t$-test; ns, non-significant. B) Protein levels were also evaluated and quantified. B-actin was used as a loading control. Data are quoted as the mean \pm SEM of at least four experiments pooled from eight filters.

ABCA7 expression was reduced, we suggest that the decrease in $\mathrm{ABCA} 7$ reported provokes a reduction of ABCA1 and APOE expression which in turn decreases lipoproteins lipidation and thus, reduces amyloid elimination across the BBB.

Lastly, by linking ABCA7 to cholesterol and amyloid exchanges across the $\mathrm{BBB}$, our results 1) revealed novel pathways underlying the association between $\mathrm{ABCA} 7$ dysfunction and $\mathrm{AD}$ pathogenesis, and 2) suggest that this transporter may be a potential therapeutic target for curing or preventing AD.
All these experiments were performed using an in vitro $\mathrm{BBB}$ model, therefore further in vivo experiments using wild-type and $A b c a 7^{-/-}$mice should to be performed to confirm the relevance of these data and to confirm the links between ABCA7, $\mathrm{BBB}$, and $\mathrm{AD}$.

\section{ACKNOWLEDGMENTS}

This work was supported by internal grants from University of Artois (BQR-ABCA7, to FG) and 
from foundation France Alzheimer et Maladies apparentées (AAP 2013, \#22, to FG). Y.L. has received fellowships from the Region Hauts-deFrance. J.P.'s work was funded by grants from the following sources: Deutsche Forschungsgemeinschaft/ Germany (DFG PA930/9, DFG PA930/12); Leibniz Society/ Germany (SAW-2015-IPB-2); HelseSØ/ Norway (2016062); Norsk forskningsrådet/ Norway (246392, 247179 (NeuroGeM), 248772, 251290, 260786 (PROP-AD)); Horizon 2020/ European Union (643417 (PROP-AD)). NeuroGeM is an EU Joint Programme - Neurodegenerative Disease Research (JPND) project. The project is funded by the following organizations under the aegis of the JPND - www.jpnd.eu (CIHR - Canada, BMBF - Germany, NRF \#247179 - Norway, ZonMW - The Netherlands). PROP-AD is an EU Joint Programme - Neurodegenerative Disease Research (JPND) project. The project is funded by the following organizations under the aegis of the JPND - www.jpnd.eu (AKA \#301228 - Finland, BMBF \#01ED1605- Germany, CSO-MOH \#30000-12631 Israel, NFR \#260786 - Norway, SRC \#2015-06795 - Sweden). This project has received funding from the European Union's Horizon 2020 research and innovation program under grant agreement \#643417 (JPco-fuND).

Authors' disclosures available online (https:// www.j-alz.com/manuscript-disclosures/17-0883r2).

\section{REFERENCES}

[1] World Health Organization, Dementia: A public health priority, http://www.who.int/mental_health/publications/dem entia_report_2012/en/, Posted 2012, Accessed 5 June 2017.

[2] Querfurth HW, LaFerla FM (2010) Alzheimer's disease. $N$ Engl J Med 362, 329-344.

[3] Xue-Shan Z, juan P, Qi W, Zhong R, Li-hong P, Zhi-han T, Zhi-Sheng J, Gui-xue W, Lu-Shan L (2016) Imbalanced cholesterol metabolism in Alzheimer's disease. Clin Chim Acta 456, 107-114.

[4] Reitz C (2013) Dyslipidemia and the risk of Alzheimer's disease. Curr Atheroscler Rep 15, 1-14.

[5] Bu G (2009) Apolipoprotein E and its receptors in Alzheimer's disease: Pathways, pathogenesis and therapy. Nat Rev Neurosci 10, 333-344.

[6] Refolo LM, Pappolla MA, Malester B, LaFrancois J, Bryant-Thomas T, Wang R, Tint GS, Sambamurti K, Duff K (2000) Hypercholesterolemia accelerates the Alzheimer's amyloid pathology in a transgenic mouse model. Neurobiol Dis 7, 321-331.

[7] Refolo LM, Pappolla MA, LaFrancois J, Malester B, Schmidt SD, Thomas-Bryant T, Tint GS, Wang R, Mercken M, Petanceska SS, Duff KE (2001) A cholesterol-lowering drug reduces beta-amyloid pathology in a transgenic mouse model of Alzheimer's disease. Neurobiol Dis 8, 890-899.
[8] Solomon A, Kivipelto M, Wolozin B, Zhou J, Whitmer RA (2009) Midlife serum cholesterol and increased risk of Alzheimer's and vascular dementia three decades later. Dement Geriatr Cogn Disord 28, 75-80.

[9] Solomon A, Kåreholt I, Ngandu T, Winblad B, Nissinen A, Tuomilehto J, Soininen H, Kivipelto M (2007) Serum cholesterol changes after midlife and late-life cognition: Twenty-one-year follow-up study. Neurology $\mathbf{6 8}$, 751-756.

[10] Löscher W, Potschka H (2005) Blood-brain barrier active efflux transporters: ATP-binding cassette gene family. NeuroRx 2, 86-98.

[11] Do TM, Ouellet M, Calon F, Chimini G, Chacun H, Farinotti R, Bourasset F (2011) Direct evidence of abca1-mediated efflux of cholesterol at the mouse blood-brain barrier. Mol Cell Biochem 357, 397-404.

[12] Kuntz M, Candela P, Saint-Pol J, Lamartinière Y, Boucau MC, Sevin E, Fenart L, Gosselet F (2015) Bexarotene promotes cholesterol efflux and restricts apical-to-basolateral transport of amyloid- $\beta$ peptides in an in vitro model of the human blood-brain barrier. J Alzheimers Dis 48, 849-862.

[13] Kim WS, Weickert CS, Garner B (2008) Role of ATPbinding cassette transporters in brain lipid transport and neurological disease. J Neurochem 104, 1145-1166.

[14] Gosselet F, Candela P, Sevin E, Berezowski V, Cecchelli R, Fenart L (2009) Transcriptional profiles of receptors and transporters involved in brain cholesterol homeostasis at the blood-brain barrier: Use of an in vitro model. Brain Res 1249, 34-42.

[15] Wang N, Lan D, Chen W, Matsuura F, Tall AR (2004) ATPbinding cassette transporters G1 and G4 mediate cellular cholesterol efflux to high-density lipoproteins. Proc Natl Acad Sci U S A 101, 9774-9779.

[16] Wang N, Yvan-Charvet L, Lütjohann D, Mulder M, Vanmierlo T, Kim T-W, Tall AR (2008) ATP-binding cassette transporters G1 and G4 mediate cholesterol and desmosterol efflux to HDL and regulate sterol accumulation in the brain. FASEB J 22, 1073-1082.

[17] Zhang DD, Yu HL, Ma WW, Liu QR, Han J, Wang H, Xiao R (2015) 27-Hydroxycholesterol contributes to disruptive effects on learning and memory by modulating cholesterol metabolism in the rat brain. Neuroscience 300, 163-173.

[18] Karasinska JM, Rinninger F, Lütjohann D, Ruddle P, Franciosi S, Kruit JK, Singaraja RR, Hirsch-Reinshagen V, Fan J, Brunham LR, Bissada N, Ramakrishnan R, Wellington CL, Parks JS, Hayden MR (2009) Specific loss of brain ABCA1 increases brain cholesterol uptake and influences neuronal structure and function. J Neurosci 29, 3579-3589.

[19] Hollingworth P, Harold D, Sims R, Gerrish A, Lambert JC, Carrasquillo MM, Abraham R, Hamshere ML, Pahwa JS, Moskvina V, Dowzell K, Jones N, Stretton A, Thomas C, Richards A, Ivanov D, Widdowson C, Chapman J, Lovestone S, Powell J, Proitsi P, Lupton MK, Brayne C, Rubinsztein DC, Gill M, Lawlor B, Lynch A, Brown KS, Passmore PA, Craig D, McGuinness B, Todd S, Holmes C, Mann D, Smith AD, Beaumont H, Warden D, Wilcock G, Love S, Kehoe PG, Hooper NM, Vardy ERLC, Hardy J, Mead S, Fox NC, Rossor M, Collinge J, Maier W, Jessen F, Rüther E, Schürmann B, Heun R, Kölsch H, van den Bussche H, Heuser I, Kornhuber J, Wiltfang J, Dichgans M, Frölich L, Hampel H, Gallacher J, Hüll M, Rujescu D, Giegling I, Goate AM, Kauwe JSK, Cruchaga C, Nowotny P, Morris JC, Mayo K, Sleegers K, Bettens K, Engelborghs S, De Deyn PP, Van Broeckhoven C, Livingston G, Bass NJ, Gurling H, McQuillin A, Gwilliam R, Deloukas P, 
Al-Chalabi A, Shaw CE, Tsolaki M, Singleton AB, Guerreiro R, Mühleisen TW, Nöthen MM, Moebus S, Jöckel K-H, Klopp N, Wichmann H-E, Pankratz VS, Sando SB, Aasly JO, Barcikowska M, Wszolek ZK, Dickson DW, Graff-Radford NR, Petersen RC, van Duijn CM, Breteler MMB, Ikram MA, DeStefano AL, Fitzpatrick AL, Lopez O, Launer LJ, Seshadri S, Berr C, Campion D, Epelbaum J, Dartigues J-F, Tzourio C, Alpérovitch A, Lathrop M, Feulner TM, Friedrich P, Riehle C, Krawczak M, Schreiber S, Mayhaus M, Nicolhaus S, Wagenpfeil S, Steinberg S, Stefansson H, Stefansson K, Snaedal J, Björnsson S, Jonsson P V, Chouraki V, Genier-Boley B, Hiltunen M, Soininen $\mathrm{H}$, Combarros O, Zelenika D, Delepine M, Bullido MJ, Pasquier F, Mateo I, Frank-Garcia A, Porcellini E, Hanon O, Coto E, Alvarez V, Bosco P, Siciliano G, Mancuso M, Panza F, Solfrizzi V, Nacmias B, Sorbi S, Bossú P, Piccardi P, Arosio B, Annoni G, Seripa D, Pilotto A, Scarpini E, Galimberti D, Brice A, Hannequin D, Licastro F, Jones L, Holmans PA, Jonsson T, Riemenschneider M, Morgan K, Younkin SG, Owen MJ, O’Donovan M, Amouyel P, Williams J (2011) Common variants at ABCA7, MS4A6A/MS4A4E, EPHA1, $\mathrm{CD} 33$ and CD2AP are associated with Alzheimer's disease. Nat Genet 43, 429-435.

[20] Steinberg S, Stefansson H, Jonsson T, Johannsdottir H, Ingason A, Helgason H, Sulem P, Magnusson OT, Gudjonsson SA, Unnsteinsdottir U, Kong A, Helisalmi S, Soininen H, Lah JJ, DemGene, Aarsland D, Fladby T, Ulstein ID, Djurovic S, Sando SB, White LR, Knudsen G-P, Westlye LT, Selbæk G, Giegling I, Hampel H, Hiltunen M, Levey AI, Andreassen OA, Rujescu D, Jonsson P V, Bjornsson S, Snaedal J, Stefansson K (2015) Loss-of-function variants in ABCA7 confer risk of Alzheimer's disease. Nat Genet 47, 445-447.

[21] Chan SL, Kim WS, Kwok JB, Hill AF, Cappai R, Rye KA, Garner B (2008) ATP-binding cassette transporter A7 regulates processing of amyloid precursor protein in vitro. J Neurochem 106, 793-804.

[22] Kim WS, Fitzgerald ML, Kang K, Okuhira KI, Bell SA, Manning JJ, Koehn SL, Lu N, Moore KJ, Freeman MW (2005) Abca7 null mice retain normal macrophage phosphatidylcholine and cholesterol efflux activity despite alterations in adipose mass and serum cholesterol levels. J Biol Chem 280, 3989-3995.

[23] Kim WS, Guillemin GJ, Glaros EN, Lim CK, Garner B (2006) Quantitation of ATP-binding cassette subfamily-A transporter gene expression in primary human brain cells. Neuroreport 17, 891-896.

[24] Fu Y, Hsiao JHT, Paxinos G, Halliday GM, Kim WS (2016) ABCA7 mediates phagocytic clearance of amyloid- $\beta$ in the brain. J Alzheimers Dis 54, 569-584.

[25] Sakae N, Liu C-C, Shinohara M, Frisch-Daiello J, Ma L, Yamazaki Y, Tachibana M, Younkin L, Kurti A, Carrasquillo MM, Zou F, Sevlever D, Bisceglio G, Gan M, Fol R, Knight P, Wang M, Han X, Fryer JD, Fitzgerald ML, Ohyagi Y, Younkin SG, Bu G, Kanekiyo T (2016) ABCA7 deficiency accelerates amyloid- $\beta$ generation and Alzheimer's neuronal pathology. J Neurosci 36, 3848-3859.

[26] Coisne C, Dehouck L, Faveeuw C, Delplace Y, Miller F, Landry C, Morissette C, Fenart L, Cecchelli R, Tremblay P, Dehouck B (2005) Mouse syngenic in vitro blood-brain barrier model: A new tool to examine inflammatory events in cerebral endothelium. Lab Invest $\mathbf{8 5}$, 734-746.

[27] Mysiorek C, Culot M, Dehouck L, Derudas B, Staels B, Bordet R, Cecchelli R, Fenart L, Berezowski V (2009)
Peroxisome proliferator-activated receptor- activation protects brain capillary endothelial cells from oxygen-glucose deprivation-induced hyperpermeability in the blood-brain barrier. Curr Neurovasc Res 6, 181-193.

[28] Kuntz M, Mysiorek C, Pétrault O, Boucau MC, Aijjou R, Uzbekov R, Bérézowski V (2014) Transient oxygen-glucose deprivation sensitizes brain capillary endothelial cells to rtPA at $4 \mathrm{~h}$ of reoxygenation. Microvasc Res 91, 44-57.

[29] Cecchelli R, Dehouck B, Descamps L, Fenart L, BuéeScherrer V, Duhem C, Lundquist S, Rentfel M, Torpier G, Dehouck MP (1999) In vitro model for evaluating drug transport across the blood-brain barrier. Adv Drug Deliv Rev 36, 165-178.

[30] Coisne C, Hallier-Vanuxeem D, Boucau MC, Hachani J, Tilloy S, Bricout H, Monflier E, Wils D, Serpelloni M, Parissaux X, Fenart L, Gosselet F (2016) $\beta$-cyclodextrins decrease cholesterol release and $\mathrm{ABC}$-associated transporter expression in smooth muscle cells and aortic endothelial cells. Front Physiol 7, 185.

[31] Saint-Pol J, Candela P, Boucau MC, Fenart L, Gosselet F (2013) Oxysterols decrease apical-to-basolateral transport of $\mathrm{A} \beta$ peptides via an $\mathrm{ABCB} 1$-mediated process in an in vitro Blood-brain barrier model constituted of bovine brain capillary endothelial cells. Brain Res 1517, 1-15.

[32] Do TM, Noel-Hudson MS, Ribes S, Besengez C, Smirnova M, Cisternino S, Buyse M, Calon F, Chimini G, Chacun H, Scherrmann JM, Farinotti R, Bourasset F (2012) ABCG2and ABCG4-mediated efflux of amyloid- $\beta$ peptide 1-40 at the mouse blood-brain barrier. J Alzheimers Dis 30, 155166.

[33] Dodacki A, Wortman M, Saubaméa B, Chasseigneaux S, Nicolic S, Prince N, Lochus M, Raveu AL, Declèves X, Scherrmann JM, Patel SB, Bourasset F (2017) Expression and function of Abcg4 in the mouse blood-brain barrier: Role in restricting the brain entry of amyloid- $\beta$ peptide. $S c i$ Rep 7, 13393.

[34] Candela P, Gosselet F, Saint-pol J, Sevin E, Boucau MC, Boulanger E, Cecchelli R, Fenart L (2010) Apicalto-basolateral transport of amyloid- $\beta$ peptides through blood-brain barrier cells is mediated by the receptor for advanced glycation end-products and is restricted by $\mathrm{P}$ glycoprotein. J Alzheimers Dis 22, 849-859.

[35] Vellonen K-S, Ihalainen J, Boucau M-C, Gosselet F, Picardat T, Gynther M, Kanninen KM, White AR, Malm T, Koistinaho J, Forsberg MM, Ruponen M (2017) Diseaseinduced alterations in brain drug transporters in animal models of Alzheimer's disease. Pharm Res 34, 2652-2662.

[36] Zhang W, Clair DS, Butterfield A, Vore M (2016) Loss of Mrp1 potentiates doxorubicin-induced cytotoxicity in neonatal mouse cardiomyocytes and cardiac fibroblasts. Toxicol Sci 151, 44-56.

[37] Candela P, Saint-Pol J, Kuntz M, Boucau MC, Lamartiniere Y, Gosselet F, Fenart L (2015) In vitro discrimination of the role of LRP1 at the BBB cellular level: Focus on brain capillary endothelial cells and brain pericytes. Brain Res 1594, 15-26.

[38] Kober AC, Manavalan APC, Tam-Amersdorfer C, Holmér A, Saeed A, Fanaee-Danesh E, Zandl M, Albrecher NM, Björkhem I, Kostner GM, Dahlbäck B, Panzenboeck U (2017) Implications of cerebrovascular ATP-binding cassette transporter $\mathrm{G} 1$ (ABCG1) and apolipoprotein $\mathrm{M}$ in cholesterol transport at the blood-brain barrier. Biochim Biophys Acta 1862, 573-588.

[39] Meurs I, Calpe-Berdiel L, Habets KLL, Zhao Y, Korporaal SJA, Mommaas AM, Josselin E, Hildebrand RB, Ye D, 
Out R, Kuiper J, Van Berkel TJC, Chimini G, Van Eck M (2012) Effects of deletion of macrophage ABCA7 on lipid metabolism and the development of atherosclerosis in the presence and absence of ABCA1. PLoS One 7, 1-13.

[40] Satoh K, Abe-Dohmae S, Yokoyama S, St. George-Hyslop P, Fraser PE (2015) ATP-binding cassette transporter A7 (ABCA7) loss of function alters Alzheimer amyloid processing. J Biol Chem 290, 24152-24165.

[41] Kim WS, Li H, Ruberu K, Chan S, Elliott DA, Low JK, Cheng D, Karl T, Garner B (2013) Deletion of Abca7 increases cerebral amyloid- $\beta$ accumulation in the J20 mouse model of Alzheimer's disease. J Neurosci 33, 4387-4394.

[42] Kaminski WE, Orsó E, Diederich W, Klucken J, Drobnik W, Schmitz G (2000) Identification of a novel human sterol-sensitive ATP-binding cassette transporter (ABCA7). Biochem Biophys Res Commun 273, 532-538.

[43] Deane R, Yan S Du, Submamaryan RK, Larue B, Jovanovic S, Hogg E, Welch D, Manness L, Lin C, Yu J, Zhu H, Ghiso J, Frangione B, Stern A, Schmidt AM, Armstrong DL, Arnold B, Liliensiek B, Nawroth P, Hofman F, Kindy M, Stern D, Zlokovic B (2003) RAGE mediates amyloid- $\beta$ peptide transport across the blood-brain barrier and accumulation in brain. Nat Med 9, 907-913.

[44] Pflanzner T, Janko MC, André-Dohmen B, Reuss S, Weggen S, Roebroek AJM, Kuhlmann CRW, Pietrzik CU (2011) LRP1 mediates bidirectional transcytosis of amyloid- $\beta$ across the blood-brain barrier. Neurobiol Aging 32, 2323.

[45] Xiong H, Callaghan D, Jones A, Bai J, Rasquinha I, Smith C, Pei K, Walker D, Lue L, Stanimirovic D, Zhang W (2009) ABCG2 Is upregulated in Alzheimer's brain with cerebral amyloid angiopathy and may act as a gatekeeper at the blood-brain barrier for Abeta 1-40 peptides. J Neurosci 29 , 5463-5475.

[46] Cirrito JR, Deane R, Fagan AM, Spinner ML, Parsadanian M, Finn MB, Jiang H, Prior JL, Sagare A, Bales KR, Paul SM, Zlokovic B V, Piwnica-worms D, Holtzman DM (2005) P-glycoprotein deficiency at the blood-brain barrier increases amyloid- $\beta$ deposition in an Alzheimer disease mouse model. J Clin Invest 115, 3285-3290.

[47] Gosselet F, Saint-Pol J, Candela P, Fenart L (2013) Amyloid$\beta$ peptides, Alzheimer's disease and the blood-brain barrier. Curr Alzheimer Res 10, 1015-1033.

[48] Ohtsuki S, Ikeda C, Uchida Y, Sakamoto Y, Miller F, Glacial F, Decleves X, Scherrmann JM, Couraud PO, Kubo Y, Tachikawa M, Terasaki T (2013) Quantitative targeted absolute proteomic analysis of transporters, receptors and junction proteins for validation of human cerebral microvascular endothelial cell line hCMEC/D3 as a human blood-brain barrier model. Mol Pharm 10, 289-296.

[49] Tai LM, Loughlin AJ, Male DK, Romero IA (2009) Pglycoprotein and breast cancer resistance protein restrict apical-to-basolateral permeability of human brain endothelium to amyloid-beta. J Cereb Blood Flow Metab 40, 1079-1083.

[50] Krohn M, Lange C, Hofrichter J, Scheffler K, Stenzel J, Steffen J, Schumacher T, Brüning T, Plath A, Alfen F, Schmidt A, Winter F, Rateitschak K, Wree A, Gsponer J, Walker LC, Pahnke J (2011) Cerebral amyloid- $\beta$ proteostasis is regulated by the membrane transport protein $\mathrm{ABCC} 1$ in mice. $J$ Clin Invest 121, 3924-3931.

[51] Hartz AMS, Miller DS, Bauer B (2010) Restoring bloodbrain barrier P-glycoprotein reduces brain amyloid-beta in a mouse model of Alzheimer's disease. Mol Pharmacol 77, 715-723.
[52] Qosa H, Abuznait AH, Hill RA, Kaddoumi A (2012) Enhanced brain amyloid-b clearance by rifampicin and caffeine as a possible protective mechanism against Alzheimer's disease. J Alzheimers Dis 31, 151-165.

[53] Wahrle SE, Jiang H, Parsadanian M, Kim J, Li A, Knoten A, Jain S, Hirsch-Reinshagen V, Wellington CL, Bales KR, Paul SM, Holtzman DM (2008) Overexpression of ABCA1 reduces amyloid deposition in the PDAPP mouse model of Alzheimer disease. J Clin Invest 118, 671-682.

[54] Koldamova RP, Lefterov IM, Staufenbiel M, Wolfe D, Huang S, Glorioso JC, Walter M, Roth MG, Lazo JS (2005) The liver X receptor ligand T0901317 decreases amyloid production in vitro and in a mouse model of Alzheimer's disease. J Biol Chem 280, 4079-4088.

[55] Koldamova RP, Lefterov IM, Ikonomovic MD, Skoko J, Lefterov PI, Isanski BA, DeKosky ST, Lazo JS (2003) 22R-hydroxycholesterol and 9-cis-retinoic acid induce ATP-binding cassette transporter A1 expression and cholesterol efflux in brain cells and decrease amyloid beta secretion. J Biol Chem 278, 13244-13256.

[56] Saint-Pol J, Vandenhaute E, Boucau MC, Candela P, Dehouck L, Cecchelli R, Dehouck MP, Fenart L, Gosselet F (2012) Brain pericytes Abca1 expression mediates cholesterol efflux but not cellular amyloid- $\beta$ peptide accumulation. J Alzheimers Dis 30, 489-503.

[57] Li H, Karl T, Garner B (2016) Abca7 deletion does not affect adult neurogenesis in the mouse. Biosci Rep 36, 1-6.

[58] Logge W, Cheng D, Chesworth R, Bhatia S, Garner B, Kim WS, Karl T (2012) Role of Abca7 in mouse behaviours relevant to neurodegenerative diseases. PLoS One 7, 1-9.

[59] Abe-Dohmae S, Ikeda Y, Matsuo M, Hayashi M, Okuhira KI, Ueda K, Yokoyama S (2004) Human ABCA7 supports apolipoprotein-mediated release of cellular cholesterol and phospholipid to generate high density lipoprotein. J Biol Chem 279, 604-611.

[60] Hayashi M, Abe-Dohmae S, Okazaki M, Ueda K, Yokoyama S (2005) Heterogeneity of high density lipoprotein generated by ABCA1 and ABCA7. J Lipid Res 46, 1703-1711.

[61] Vaughan AM, Oram JF (2006) ABCA1 and ABCG1 or ABCG4 act sequentially to remove cellular cholesterol and generate cholesterol-rich HDL. J Lipid Res 47, 2433-2443.

[62] Tarr PT, Edwards PA (2008) ABCG1 and ABCG4 are coexpressed in neurons and astrocytes of the CNS and regulate cholesterol homeostasis through SREBP-2. J Lipid Res 49, 169-182.

[63] Martins IJ, Berger T, Sharman MJ, Verdile G, Fuller SJ, Martins RN (2009) Cholesterol metabolism and transport in the pathogenesis of Alzheimer's disease. J Neurochem 111, 1275-1308.

[64] Gosselet F (2012) How ApoE regulates blood-brain barrier integrity. Med Sci (Paris) 28, 920-923.

[65] Hirsch-Reinshagen V, Maia LF, Burgess BL, Blain JF, Naus KE, McIsaac SA, Parkinson PF, Chan JY, Tansley GH, Hayden MR, Poirier J, Van Nostrand W, Wellington CL (2005) The absence of ABCA1 decreases soluble ApoE levels but does not diminish amyloid deposition in two murine models of Alzheimer disease. J Biol Chem 280, 43243-43256.

[66] Koldamova R, Staufenbiel M, Lefterov I (2005) Lack of ABCA1 considerably decreases brain ApoE level and increases amyloid deposition in APP23 mice. J Biol Chem 280, 43224-43235.

[67] Wahrle SE, Jiang H, Parsadanian M, Hartman RE, Bales KR, Paul SM, Holtzman DM (2005) Deletion of Abca1 increases 
Abeta deposition in the PDAPP transgenic mouse model of Alzheimer disease. J Biol Chem 280, 43236-43242.

[68] Iwamoto N, Abe-Dohmae S, Sato R, Yokoyama S (2006) ABCA7 expression is regulated by cellular cholesterol through the SREBP2 pathway and associated with phagocytosis. J Lipid Res 47, 1915-1927.

[69] Leoni V, Caccia C (2015) The impairment of cholesterol metabolism in Huntington disease. Biochim Biophys Acta 1851, 1095-1105.

[70] Maejima T, Sugano T, Yamazaki H, Yoshinaka Y, Doi T, Tanabe S, Nishimaki-Mogami T (2011) Pitavastatin increases ABCA1 expression by dual mechanisms:
SREBP2-driven transcriptional activation and PPAR $\alpha$ dependent protein stabilization but without activating LXR in rat hepatoma McARH7777 cells. J Pharmacol Sci 116, 107-115.

[71] Merino-Zamorano C, Retana SF De, Montañola A, Batlle A, Saint-Pol J, Mysiorek C, Gosselet F, Montaner J, Hernández-Guillamon M (2016) Modulation of amyloid31-40 transport by ApoA 1 and ApoJ across an in vitro model of the blood-brain barrier. J Alzheimers Dis 53, 677-691. 